\title{
Nitrogen cycling in Sandusky Bay, Lake Erie: oscillations between strong and weak export and implications for harmful algal blooms
}

\author{
Kateri R. Salk ${ }^{1}$, George S. Bullerjahn ${ }^{2}$, Robert Michael L. McKay ${ }^{2}$, Justin D. Chaffin ${ }^{3}$, and Nathaniel E. Ostrom ${ }^{1}$ \\ ${ }^{1}$ Department of Integrative Biology, Michigan State University, East Lansing, MI 48824, USA \\ ${ }^{2}$ Department of Biological Sciences, Bowling Green State University, Bowling Green, OH 43403, USA \\ ${ }^{3}$ F.T. Stone Laboratory Ohio Sea Grant, The Ohio State University, Put-in-Bay, OH 43456, USA
}

Correspondence: Kateri R. Salk (krsalkgu@uwaterloo.ca)

Received: 7 December 2017 - Discussion started: 16 January 2018

Revised: 25 April 2018 - Accepted: 26 April 2018 - Published: 16 May 2018

\begin{abstract}
Recent global water quality crises point to an urgent need for greater understanding of cyanobacterial harmful algal blooms (cHABs) and their drivers. Nearshore areas of Lake Erie such as Sandusky Bay may become seasonally limited by nitrogen $(\mathrm{N})$ and are characterized by distinct cHAB compositions (i.e., Planktothrix over Microcystis). This study investigated phytoplankton $\mathrm{N}$ uptake pathways, determined drivers of $\mathrm{N}$ depletion, and characterized the $\mathrm{N}$ budget in Sandusky Bay. Nitrate $\left(\mathrm{NO}_{3}^{-}\right)$and ammonium $\left(\mathrm{NH}_{4}^{+}\right)$uptake, $\mathrm{N}$ fixation, and $\mathrm{N}$ removal processes were quantified by stable isotopic approaches. Dissimilatory $\mathrm{N}$ reduction was a relatively modest $\mathrm{N}$ sink, with denitrification, anammox, and $\mathrm{N}_{2} \mathrm{O}$ production accounting for 84,14 , and $2 \%$ of sediment $\mathrm{N}$ removal, respectively. Phytoplankton assimilation was the dominant $\mathrm{N}$ uptake mechanism, and $\mathrm{NO}_{3}^{-}$uptake rates were higher than $\mathrm{NH}_{4}^{+}$uptake rates. Riverine $\mathrm{N}$ loading was sometimes insufficient to meet assimilatory and dissimilatory demands, but $\mathrm{N}$ fixation alleviated this deficit. $\mathrm{N}$ fixation made up $23.7-85.4 \%$ of total phytoplankton $\mathrm{N}$ acquisition and indirectly supports Planktothrix blooms. However, $\mathrm{N}$ fixation rates were surprisingly uncorrelated with $\mathrm{NO}_{3}^{-}$or $\mathrm{NH}_{4}^{+}$concentrations. Owing to temporal separation in sources and sinks of $\mathrm{N}$ to Lake Erie, Sandusky Bay oscillates between a conduit and a filter of downstream $\mathrm{N}$ loading to Lake Erie, delivering extensively recycled forms of $\mathrm{N}$ during periods of low export. Drowned river mouths such as Sandusky Bay are mediators of downstream $\mathrm{N}$ loading, but climate-change-induced increases in precipitation and $\mathrm{N}$ loading will likely intensify $\mathrm{N}$ export from these systems.
\end{abstract}

\section{Introduction}

Harmful algal blooms (HABs) are increasing in frequency on a global scale and are stimulated by excessive nutrient loading to aquatic systems (Bricker et al., 2008; Heisler et al., 2008). Lake Erie, in particular, has been subject to increased incidence and expansion of cyanobacterial HABs (cHABs) in recent years (Michalak et al., 2013; Ho and Michalak, 2015; Bullerjahn et al., 2016). These blooms are dominated by cyanobacteria that accumulate the powerful hepatotoxin, microcystin (Carmichael and Boyer, 2016). A more nuanced understanding of the drivers of cHABs, including nutrient cycling, will allow for better prediction and management of blooms in Lake Erie and other ecosystems.

Phytoplankton biomass and cHABs in Lake Erie have historically been correlated with P loading from river inflows (Kane et al., 2014; Kim et al., 2014). Calls to control eutrophication in Lake Erie have proposed targets for reduced P loading but have largely ignored N (Scavia et al., 2014). However, there is a growing dialogue surrounding the dual management of $\mathrm{N}$ and $\mathrm{P}$ in lacustrine systems (Gobler at al., 2016; Paerl et al., 2016), particularly as co-limitation of phytoplankton growth by both $\mathrm{N}$ and $\mathrm{P}$ has been demonstrated in the late summer in Lake Erie (Moon and Carrick, 2007; North et al., 2007; Chaffin et al., 2013; Steffen et al., 2014a). This seasonal $\mathrm{N}$ deficiency is consistent with reduced watershed loading of $\mathrm{N}$ into the lake's western basin over the past two decades (Stow et al., 2015) combined with active dissimilatory sinks for nitrate (Small et al., 2016). N concentration and speciation also influence toxin production by cHABs (Horst et al., 2014; Monchamp et al., 2014; Davis et al., 2015). Delineating the role of $\mathrm{N}$ in controlling cHABs, 
therefore, requires the investigation of spatial and temporal variation in multiple species of $\mathrm{N}$.

Because the Lake Erie catchment is highly agricultural, the majority of bioavailable $\mathrm{N}$ in the lake is derived from farming practices and delivered to the lake via river inflows (Robertson and Saad, 2011; Stow et al., 2015). Once in the lake, dissolved inorganic N (DIN) and dissolved organic $\mathrm{N}$ (DON) are subject to consumption by competing biological processes. Phytoplankton, including cHAB taxa, commonly take up DIN and DON in the form of ammonium $\left(\mathrm{NH}_{4}^{+}\right)$, nitrate $\left(\mathrm{NO}_{3}^{-}\right)$, and urea (Davis et al., 2015). $\mathrm{N}$ fixation, an alternate source of bioavailable $\mathrm{N}$, is expected to occur when DIN is scarce. $\mathrm{N}$ fixation activity has been inferred in Lake Erie (MacGregor et al., 2001; Monchamp et al., 2014; Steffen et al., 2014a; Davis et al., 2015) but not quantified for several decades (Howard et al., 1970). Dissimilatory microbial processes may also consume DIN in sediments, representing pathways of permanent $\mathrm{N}$ removal whereby $\mathrm{N}$ leaves the system as $\mathrm{N}_{2}$. Denitrification is expected to be the dominant microbial $\mathrm{N}$ removal pathway in freshwaters (Seitzinger et al., 2006), although anammox, a competing pathway, has not been extensively studied in freshwater systems (Yoshinaga et al., 2011; Zhu et al., 2013). Nitrous oxide $\left(\mathrm{N}_{2} \mathrm{O}\right)$, a potent greenhouse gas, is a byproduct of denitrification and nitrification (Wrage et al., 2001) and is a detrimental consequence of microbial $\mathrm{N}$ removal.

Whereas the colonial cyanobacterium Microcystis dominates the $\mathrm{cHAB}$ community in offshore regions of western Lake Erie, filamentous Planktothrix has been shown to persist in N-limited bays and tributaries (Conroy et al., 2007; Kutovaya et al., 2012; Davis et al., 2015). With few exceptions (Pancrace et al., 2017), both cHAB taxa are incapable of $\mathrm{N}$ fixation and require dissolved forms of $\mathrm{N}$ for growth. Planktothrix is a superior scavenger for N (Conroy et al., 2007) and responds strongly to additions of DIN (Donald et al., 2011, 2013). Under N limitation, Planktothrix may thus be able to outcompete other phytoplankton for small $\mathrm{N}$ inputs. Planktothrix is also particularly well-adapted to low irradiances; suspended sediment that rapidly attenuates light is often found in Planktothrix-dominated waters (Scheffer et al., 1997; Havens et al., 2003; Oberhaus et al., 2007). Additionally, Planktothrix can tolerate the widest temperature range among major bloom-forming cyanobacteria, including Microcystis, Aphanizomenon, and Dolichospermum (Anabaena) (Foy et al., 1976; Post et al., 1985). Due to these factors, the persistence of Planktothrix in nearshore zones likely operates under a fundamentally different paradigm than offshore Microcystis blooms, and mitigation may require attention to the distinct biogeochemical functioning of these genera in the nearshore vs. offshore zones.

Sandusky Bay, a drowned river mouth on the southern shore of Lake Erie, serves as an ideal location in which to examine the relationship between $\mathrm{N}$ cycling and cHABs. This system is hypereutrophic (Ostrom et al., 2005), with the cyanobacterium Planktothrix dominating phytoplankton biomass from May to October and N-fixing phytoplankton making up a small portion of the biomass (Davis et al., 2015). Sandusky Bay experiences large fluctuations in $\mathrm{NO}_{3}^{-}$concentrations and dissolved N:P ratios throughout the summer (Davis et al., 2015; Conroy et al., 2017), suggesting that the dynamic $\mathrm{N}$ cycling may influence cHAB formation in this system. Indeed, the growth of Planktothrix in Sandusky Bay is stimulated by additions of $\mathrm{NO}_{3}^{-}, \mathrm{NH}_{4}^{+}$, and urea, indicating that phytoplankton growth is seasonally limited or colimited by N (Chaffin and Bridgeman, 2014; Davis et al., 2015). Evaluating the mechanisms that promote the persistence of Planktothrix in this system will benefit from an examination of $\mathrm{N}$ removal processes and inputs from $\mathrm{N}$ fixation that directly influence the availability of DIN. A thorough understanding of these processes will also inform the capacity for Sandusky Bay to mediate nutrient delivery to Lake Erie.

The objectives of this study, conducted in Sandusky Bay, Lake Erie, were to (1) investigate the pathways by which the Planktothrix-dominated phytoplankton community acquires $\mathrm{N}$, (2) determine the factors driving $\mathrm{N}$ depletion, namely microbial $\mathrm{N}$ removal processes and hydrology, and (3) evaluate Sandusky Bay as a river-lake mixing zone in which $\mathrm{N}$ cycling affects cHABs and $\mathrm{N}$ loading to Lake Erie. These objectives provide insight into the Grand Challenges of Great Lakes research by addressing variability in ecosystem processes, anthropogenic nutrient forcing and potential for reversibility, and the response of this ecosystem to climate change (Sterner et al., 2017).

\section{Methods}

\subsection{Field sampling}

Sampling took place between May and October in 2015 and 2016 in partnership with the Ohio Department of Natural Resources (ODNR). Water column nutrient and chlorophyll (chl) $a$ samples were collected weekly in 2015 and approximately biweekly in 2016. Samples for DIN uptake assays (2016), N fixation assays (2015 and 2016), and microbial $\mathrm{N}$ removal assays (2015) were collected monthly. Six stations were sampled: two stations in the inner portion of Sandusky Bay (ODNR4, ODNR6), three stations in the outer portion of Sandusky Bay (ODNR2, ODNR1, and Environment and Climate Change Canada (ECCC) 1163, hereafter 1163), and one station directly outside Sandusky Bay in Lake Erie (Bells; Fig. 1). Tributary discharge data from the primary water source to Sandusky Bay, the Sandusky River, were obtained from the USGS stream monitoring station near Fremont, OH (site 04198000; Fig. 1). Hydraulic residence time in Sandusky Bay was estimated by dividing the Bay volume $\left(0.26 \mathrm{~km}^{3}\right.$; Richards and Baker, 1985) by the Sandusky River discharge rate. $\mathrm{NO}_{3}^{-}$and total Kjeldahl $\mathrm{N}$ (TKN) concentrations in the Sandusky River near the USGS monitoring site were provided by the Heidelberg Tributary Loading Pro- 


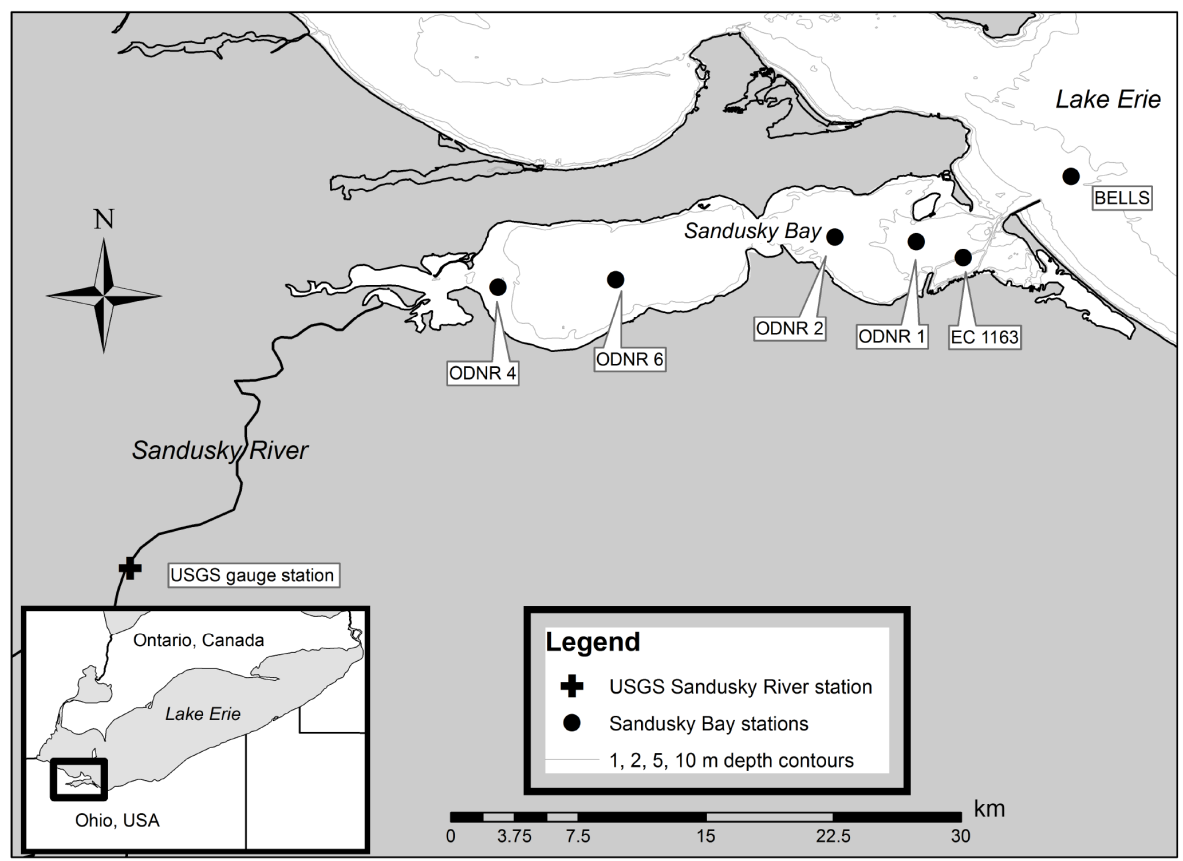

Figure 1. Sampling locations in Sandusky Bay (circles) and Sandusky River monitoring station (USGS monitoring station 04198000, cross).

gram maintained by the National Center for Water Quality Research (NCWQR) at Heidelberg University (Richards et al., 2010).

At each sampling location, water column physical and chemical parameters $(\mathrm{pH}$, conductivity, temperature, dissolved oxygen) were measured using a YSI $600 \mathrm{QS}$ sonde (YSI Inc., Yellow Springs, OH, USA). Water samples were collected by Van Dorn bottle at $1 \mathrm{~m}$ depth for the analysis of $\mathrm{NO}_{3}^{-}, \mathrm{NH}_{4}^{+}$, phosphate $\left(\mathrm{PO}_{4}^{3-}\right)$, TKN, chl $a$ concentrations, and 16S rRNA metagenomics. Samples for dissolved nutrient analysis were filtered immediately upon collection $(0.2 \mu \mathrm{m})$, kept on ice, and frozen upon return to the lab. Unfiltered sample water was collected for TKN analysis and also frozen. Samples for the determination of chl $a$ concentrations were collected on $0.2 \mu \mathrm{m}$ polycarbonate membrane filters and frozen. Samples for metagenomics analyses were collected using Sterivex cartridge filters $(0.22 \mu \mathrm{m}$; EMD Millipore, Billerica, MA, USA) which were immediately frozen on dry ice prior to storage at $-80^{\circ} \mathrm{C}$. Station 1163 has an extensive monitoring history by ECCC and was chosen for additional water and sediment assays. An additional $20 \mathrm{~L}$ carboy was filled with surface water from station 1163 for $\mathrm{N}$ uptake assays and sediment incubations. Sediment cores for the evaluation of microbial $\mathrm{N}$ removal rates (denitrification, anammox, and $\mathrm{N}_{2} \mathrm{O}$ production) by the isotope pairing technique (IPT) were collected at station 1163 using a modified piston corer as described by Smit and Steinman (2015). Given the shallow and well-oxygenated nature of the bay, microbial $\mathrm{N}$ removal in the water column was not considered. Intact sediment cores were collected in polycarbonate tubes $(7 \mathrm{~cm}$ i.d.) to a depth of $25 \mathrm{~cm}$. Water $(1 \mathrm{~cm})$ was maintained overlying the sediment during transport to preserve redox gradients.

\subsection{Nutrient and chlorophyll $a$ analyses}

Concentrations of $\mathrm{NO}_{3}^{-}+\mathrm{NO}_{2}^{-}, \mathrm{NO}_{2}^{-}, \mathrm{NH}_{4}^{+}$, and $\mathrm{PO}_{4}^{3-}$ were measured on field-filtered sample water using standard U.S. EPA methods (353.1, 353.2, 350.1, and 365.1, respectively) on a SEAL Analytical QuAAttro continuous segmented flow analyzer (SEAL Analytical Inc., Mequon, WI, USA). $\mathrm{NO}_{3}^{-}$concentration was determined as the difference between $\mathrm{NO}_{3}^{-}+\mathrm{NO}_{2}^{-}$and $\mathrm{NO}_{2}^{-}$. TKN was determined on unfiltered water after sulfuric-acid-copper-sulfate digestion at $180^{\circ} \mathrm{C}$ for $60 \mathrm{~min}$ and $380^{\circ} \mathrm{C}$ for $120 \mathrm{~min}$ and was then quantified as $\mathrm{NH}_{3}$ on the SEAL analyzer (U.S. EPA method 351.2). Seven known concentration standard solutions (including 0$)$ were used for the standard curve $\left(R^{2}>\right.$ $0.999)$, and every 10th sample was spiked with a known amount of analyte to ensure high accuracy and precision throughout the analysis (>95\% recovery). Samples with concentrations exceeding the highest standard were diluted and reanalyzed. Values were averaged over two or three replicates. Method detection limits were $0.165,0.044,0.558$, 0.044 , and $1.44 \mu \mathrm{molL} \mathrm{L}^{-1}$ for $\mathrm{NO}_{3}^{-}+\mathrm{NO}_{2}^{-}, \mathrm{NO}_{2}^{-}, \mathrm{NH}_{4}^{+}$, $\mathrm{PO}_{4}^{3-}$, and TKN, respectively. Extractive chl $a$ concentration was measured following Welschmeyer (1994). Filters containing phytoplankton seston were extracted with $90 \%$ aqueous acetone overnight at $-20^{\circ} \mathrm{C}$ followed by the measure- 
ment of the clarified extract by fluorometry (model TD-700, Turner Designs, Sunnyvale, CA, USA).

\subsection{S rRNA metagenomic analysis}

DNA was extracted using the PowerWater Sterivex DNA Isolation Kit (MO BIO Laboratories, Inc, Carlsbad, CA, USA) following manufacturer's instructions. Short 16S rRNA Illumina amplicon tag (iTag) sequencing of the V4-V5 hypervariable region of bacterial genomes was completed at the Joint Genome Institute (JGI; Walnut Creek, CA, USA) using an Illumina MiSeq benchtop sequencer $(2 \times 301$ bp reads $)$ according to standard JGI procedures (Tremblay et al., 2015). Primer design for universal amplification of the V4-V5 region of 16S rDNA was based on Parada et al. (2016). Resulting sequences were demultiplexed, and contaminating Illumina adaptor sequences were removed using the k-mer filter in BBDuk (v37.62) following Singer et al. (2016). Briefly, BBDuk was used to remove reads containing more than $1^{\prime} \mathrm{N}^{\prime}$ base or with a quality score $<10$ across the read or a length $\leq 51$ bp or $33 \%$ of the full length read. Additional processing using BBMap (http://bbtools.jgi.doe.gov, last access: 19 January 2018) mapped reads to masked human, cat, dog, and mouse references, discarding hits exceeding $93 \%$ identity (Singer et al., 2016).

Processing, clustering, and classification of sequenced reads was performed as described previously (Tremblay et al., 2015). Briefly, quality-controlled reads were processed by iTagger (v2.2), first by read clustering (97\% identity) using algorithms in USEARCH (v9.2 ; Edgar, 2010), followed by the assignment of operational taxonomic units (OTUs) using the SILVA 16S SSU database (v128; Quast et al., 2013), and, finally, the analysis of ecological data using QIIME v1.9.1 (Caporaso et al., 2010).

\subsection{Sediment microbial $N$ removal}

Upon return to the lab, water from station 1163 was gently added to cores to a depth of $20 \mathrm{~cm}$. Cores were preincubated for $12 \mathrm{~h}$ in the dark at in situ temperature under gentle aeration to maintain oxic conditions in the overlying water. Following preincubation of sediment cores, a sample was taken from the overlying water for DIN concentration analysis $\left(\mathrm{NO}_{3}^{-}, \mathrm{NO}_{2}^{-}\right.$, and $\left.\mathrm{NH}_{4}^{+}\right)$, filtered through a precombusted GF/F filter and frozen until analysis. ${ }^{15} \mathrm{~N}-\mathrm{NO}_{3}^{-}$ $\left(100 \mu \mathrm{mol} \mathrm{L}^{-1}\right)$ was then added to the overlying water in each core. Cores were then capped and statically incubated under gentle stirring throughout the duration of the experiment. An initial equilibration period was employed to allow the homogenization of $\mathrm{NO}_{3}^{-}$between the overlying water and the $\mathrm{NO}_{3}^{-}$reduction zone in the sediment porewater (Dalsgaard et al., 2000). Cores were sacrificed in triplicate or quadruplicate at intervals of 0,3 or 4 , and $6 \mathrm{~h}$, during which time oxic conditions were maintained in the overlying water. Dissolved $\mathrm{O}_{2}$ in the overlying water was monitored to evaluate the maintenance of oxic conditions throughout the incubation using a YSI 600 QS sonde. A final sample for DIN analysis was collected when each core was sacrificed and processed as described above.

Samples for the determination of $\delta^{15} \mathrm{~N}_{2}$ were collected according to Hamilton and Ostrom (2007); briefly, dissolved gases were equilibrated with a $\mathrm{He}$ atmosphere, and the headspace was transferred into a pre-evacuated $12 \mathrm{~mL}$ Exetainer (Labco Ltd, Lampeter, Ceredigion, UK). Samples for the analysis of dissolved $\mathrm{N}_{2}$ concentrations were siphoned into $12 \mathrm{~mL}$ Exetainers to overflowing and amended with $200 \mu \mathrm{L}$ of saturated $\mathrm{ZnCl}_{2}$ solution to halt biological activity. All Exetainers were stored underwater at room temperature to minimize the diffusion of atmospheric $\mathrm{N}_{2}$ during storage. Samples for the analysis of the $\delta^{15} \mathrm{~N}_{2} \mathrm{O}$ and $\mathrm{N}_{2} \mathrm{O}$ concentrations were siphoned into 250 and $60 \mathrm{~mL}$ serum bottles, respectively, to overflowing and sealed without a headspace with a butyl rubber septum. Biological activity was halted by adding saturated $\mathrm{HgCl}_{2}$ solution to a final concentration of $0.4 \%$ by volume.

Prior to $\mathrm{N}_{2} \mathrm{O}$ concentration analysis, a headspace of $20 \mathrm{~mL}$ He was introduced in each $60 \mathrm{~mL}$ bottle, maintaining atmospheric pressure with a vent needle. Serum bottles were allowed to equilibrate under gentle shaking for at least $12 \mathrm{~h}$ prior to analysis. The headspace was analyzed by a gas chromatograph interfaced to an electron capture detector (GCECD; Shimadzu greenhouse gas analyzer GC-2014, Shimadzu Scientific Instruments, Columbia, MD, USA) for $\mathrm{N}_{2} \mathrm{O}$ concentration. The dissolved concentration was calculated based on the headspace equilibrium concentration (Hamilton and Ostrom, 2007).

The isotopic composition of $\mathrm{N}_{2} \mathrm{O}$ was analyzed upon the introduction of sample water into an enclosed $0.75 \mathrm{~L}$ glass vessel that was previously purged of atmospheric air using a gentle flow of He. Dissolved gases were subsequently stripped from the water by sparging the sample with He (Sansone et al., 1997), which carried sample gases into an Isoprime Trace Gas sample introduction system interfaced to an Isoprime isotope ratio mass spectrometer (IRMS; Elementar Americas, Inc., Mount Laurel, NJ, USA).

Concentrations of dissolved $\mathrm{N}_{2}$ were analyzed by membrane inlet mass spectrometry (MIMS; Kana et al., 1994). The isotopic composition of $\mathrm{N}_{2}$ was analyzed by introducing the sample to an evacuated $800 \mu \mathrm{L}$ sampling loop and then onto a packed molecular sieve ( $5 \AA$ ) column (Alltech, Inc., Deerfield, IL) using He carrier gas within a gas chromatograph (HP-5980, Hewlett Packard, Ramsey, MN) interfaced to an Isoprime IRMS. The analytical reproducibility of standards was $0.3 \%$.

Denitrification, anammox, and $\mathrm{N}_{2} \mathrm{O}$ production rates were calculated by the IPT. Calculations were derived from the $\mathrm{IPT}_{\mathrm{anaN}_{2} \mathrm{O}}$ (Hsu and Kao, 2013), which builds on the revised IPT (R-IPT; Risgaard-Petersen et al., 2003) by enabling the quantification of $\mathrm{N}_{2} \mathrm{O}$ production simultaneously with denitrification and anammox. This approach relies on the as- 
sumption that $\mathrm{N}$ removal is limited by $\mathrm{N}$ and not by other factors such as $\mathrm{C}$, an assumption that has been supported for Sandusky Bay by Small et al. (2016). Briefly, $\mathrm{N}_{2}$ production by denitrification $\left(D_{14-\mathrm{N}_{2}}\right)$ and anammox $\left(A_{14}\right)$ was calculated as

$D_{14-\mathrm{N}_{2}}=\left(r_{14-\mathrm{N}_{2} \mathrm{O}}+1\right) \times 2 r_{14-\mathrm{N}_{2} \mathrm{O}} \times P_{30}$

and

$A_{14}=2 r_{14-\mathrm{N}_{2} \mathrm{O}} \times\left(P_{29}-2 r_{14-\mathrm{N}_{2} \mathrm{O}} \times P_{30}\right)$,

where $r_{14-\mathrm{N}_{2} \mathrm{O}}$ is the ratio of ${ }^{14} \mathrm{~N}$ to ${ }^{15} \mathrm{~N}$ in $\mathrm{N}_{2} \mathrm{O} . P_{29}$ and $P_{30}$, the production of ${ }^{29} \mathrm{~N}_{2}$ and ${ }^{30} \mathrm{~N}_{2}$, respectively, were calculated by the increase in isotope fraction of mass 29 or 30 as measured by IRMS and corrected for the change in total $\mathrm{N}_{2}$ concentration as measured by MIMS. $\mathrm{N}_{2} \mathrm{O}$ production $\left(D_{14-\mathrm{N}_{2} \mathrm{O}}\right)$ was calculated as

$D_{14-\mathrm{N}_{2} \mathrm{O}}=r_{14-\mathrm{N}_{2} \mathrm{O}} \times\left(2 P_{46}+P_{45}\right)$,

where $P_{45}$ and $P_{46}$ are the production of ${ }^{45} \mathrm{~N}_{2} \mathrm{O}$ and ${ }^{46} \mathrm{~N}_{2} \mathrm{O}$, respectively. $P_{45}$ and $P_{46}$ were calculated by the increase in isotope fraction of mass 45 or 46 as measured by IRMS and corrected for the change in total $\mathrm{N}_{2} \mathrm{O}$ concentration as measured by GC-ECD.

\subsection{Phytoplankton $\mathrm{N}$ uptake}

DIN uptake assays were conducted by adding ${ }^{15} \mathrm{NO}_{3}^{-}$or ${ }^{15} \mathrm{NH}_{4}^{+}$to a serum bottle containing site water to a target concentration of $10 \%$ of ambient $\mathrm{NO}_{3}^{-}$or $\mathrm{NH}_{4}^{+}$concentration, respectively. Each assay for a single site was run in triplicate. Bottles were placed in an incubator at in situ light intensity, light: dark cycle, and temperature conditions for $24 \mathrm{~h}$.

$\mathrm{N}$ fixation assays were conducted by the dissolution method, which involves the addition of ${ }^{15} \mathrm{~N}_{2}$-equilibrated water to a water sample rather than a ${ }^{15} \mathrm{~N}_{2}$ bubble (Großkopf et al., 2012). Preparation of ${ }^{15} \mathrm{~N}_{2}$-equilibrated water involved sparging water in a serum bottle equipped with a butyl rubber septum with $\mathrm{He}$ to remove ambient $\mathrm{N}_{2}$, followed by the injection of ${ }^{15} \mathrm{~N}_{2}$ (98\% atom fraction, Sigma-Aldrich lot no. MBBB0968V) while maintaining atmospheric pressure with a vent needle. Water from station 1163 was transferred into $1.18 \mathrm{~L}$ serum bottles and amended with ${ }^{15} \mathrm{~N}_{2}$-equilibrated water to a final dissolved atom fraction of $1.14-2.33 \%$. Each assay for a single site was run in triplicate. Bottles were incubated at in situ light and temperature conditions for $24 \mathrm{~h}$.

To evaluate the potential contamination of ${ }^{15} \mathrm{~N}_{2}$ gas with ${ }^{15} \mathrm{NO}_{3}^{-}$or ${ }^{15} \mathrm{NH}_{4}^{+}$(Dabundo et al., 2014), a mass scan of the isotopically enriched gas was performed by IRMS. The mass scan revealed that potential impurities made up $<1 \%$ of the enriched gas. A hypothetical calculation of the incorporation of ${ }^{15} \mathrm{NO}_{3}^{-}$and ${ }^{15} \mathrm{NH}_{4}^{+}$, given maximum contamination of the $\mathrm{N}_{2}$ gas according to Dabundo et al. (2014) and maximum assimilation by phytoplankton, revealed that contamination could have made up between 0 and $5 \%$ of measured $\mathrm{N}$ fixation rates.

When DIN uptake and $\mathrm{N}$ fixation incubations were complete, the samples were vacuum filtered through precombusted GF/F filters. Filters were then dried at $60^{\circ} \mathrm{C}$, acidified with $10 \% \mathrm{HCl}$ to remove carbonates, and dried again. The concentration and isotopic composition of particulate organic matter (POM) from $\mathrm{N}$ fixation assays was analyzed by scraping the contents of dried and acidified filters into tin cups and introducing samples to an elemental analyzer interfaced to an Isoprime IRMS. The analytical reproducibility of standards was $0.2 \%$.

DIN uptake rates were calculated according to Dugdale and Wilkerson (1986). The transport rate, or $\mathrm{N}$ uptake rate $\left(\rho_{\mathrm{t}} ; \mu \mathrm{molNL} \mathrm{N}^{-1} \mathrm{~h}^{-1}\right)$, was calculated as

$\rho_{\mathrm{t}}=\frac{{ }^{15} \mathrm{~N}_{\mathrm{xs}}}{\left({ }^{15} \mathrm{~N}_{\mathrm{enr}}-{ }^{15} \mathrm{~N}_{\mathrm{na}}\right) \times T} \times \mathrm{PON}_{\mathrm{t}}$,

where ${ }^{15} \mathrm{~N}_{\mathrm{xs}}$ is the atom percent ${ }^{15} \mathrm{~N}$ excess in the POM sample, ${ }^{15} \mathrm{~N}_{\mathrm{enr}}$ is the isotope fraction of ${ }^{15} \mathrm{~N}$ in the $\mathrm{NO}_{3}^{-}$or $\mathrm{NH}_{4}^{+}$ pool, and ${ }^{15} \mathrm{~N}_{\text {na }}$ is the isotope fraction of ${ }^{15} \mathrm{~N}$ in the natural abundance POM. $T$ is the time in hours, and $\mathrm{PON}_{\mathrm{t}}$ is the concentration of $\mathrm{N}$ in POM $\left(\mu \mathrm{molNL} \mathrm{N}^{-1}\right)$ at the end of the incubation.

$\mathrm{N}$ fixation rates were calculated according to Montoya et al. (1996). The transport rate, or $\mathrm{N}$ fixation rate $\left(\rho_{\mathrm{t}}\right.$; $\mu \mathrm{mol} \mathrm{NL} \mathrm{N}^{-1} \mathrm{~h}^{-1}$ ), was calculated as

$\rho_{\mathrm{t}}=\frac{A_{\mathrm{PN}_{\mathrm{f}}}-A_{\mathrm{PN}_{0}}}{\left(A_{\mathrm{N}_{2}}-A_{\mathrm{PN}_{0}}\right) \times T} \times \mathrm{PON}_{\mathrm{t}}$,

where $A_{\mathrm{PN}_{0}}$ and $A_{\mathrm{PN}_{\mathrm{f}}}$ are the isotope fractions of ${ }^{15} \mathrm{~N}$ in the $\mathrm{POM}$ at the start and end of the incubation, respectively, and $A_{\mathrm{N}_{2}}$ is the isotope fraction of ${ }^{15} \mathrm{~N}$ in the labeled $\mathrm{N}_{2}$ pool. Areal $\mathrm{N}$ fixation rates were calculated by scaling volumetric rates over the depth of the photic zone in proportion to light attenuation, under the assumption that water column $\mathrm{N}$ fixation is light-dependent (Scott and Grantz, 2013).

\section{$2.6 \quad \mathrm{~N}$ budget}

Hourly $\mathrm{N}$ cycling rates were converted to daily rates by multiplying by the hours of daylight $(11.25-15 \mathrm{~h})$ for phytoplankton $\mathrm{N}$ uptake and $\mathrm{N}$ fixation and by $24 \mathrm{~h}$ for sediment $\mathrm{N}$ removal processes (denitrification, anammox, and $\mathrm{N}_{2} \mathrm{O}$ production). These calculations assumed that phytoplankton $\mathrm{N}$ uptake and $\mathrm{N}$ fixation were light-dependent but sediment $\mathrm{N}$ removal was light-independent. In order to generate a preliminary budget of the magnitude of $\mathrm{N}$ sources and sinks in Sandusky Bay, total daily loads of each process for the entire system $\left(\mathrm{kg} \mathrm{d}^{-1}\right)$ were calculated by scaling up volumetric measurements (phytoplankton uptake, $\mathrm{N}$ fixation) and areal measurements (denitrification, anammox, $\mathrm{N}_{2} \mathrm{O}$ production) to the volume $\left(0.26 \mathrm{~km}^{3}\right)$ and area $\left(162 \mathrm{~km}^{2}\right)$ of Sandusky Bay, respectively. The total $\mathrm{NO}_{3}^{-}$and TKN load to Sandusky Bay 

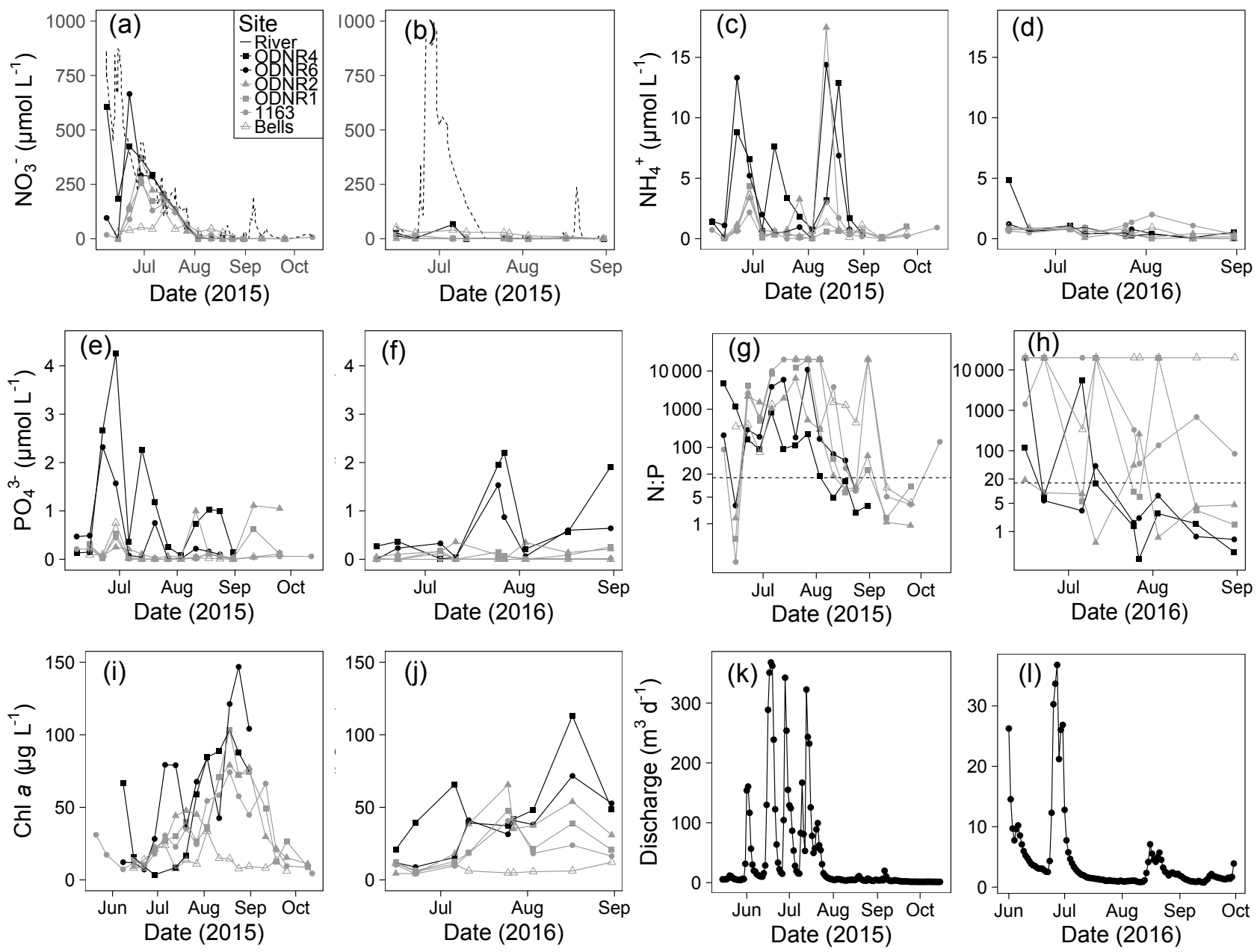

Figure 2. (a, b) $\mathrm{NO}_{3}^{-},(\mathbf{c}, \mathbf{d}) \mathrm{NH}_{4}^{+},(\mathbf{e}, \mathbf{f}) \mathrm{PO}_{4}^{3-},(\mathbf{g}, \mathbf{h}) \mathrm{N}: \mathrm{P}\left(\mathrm{NO}_{3}^{-}+\mathrm{NH}_{4}^{+}: \mathrm{PO}_{4}^{3-}\right)$ ratio, (i, j) chlorophyll $a$, and (k, l) Sandusky River discharge, in 2015 and 2016. Six Sandusky Bay sites are presented: the inner bay (ODNR and ODNR6; black filled symbols), the outer bay (ODNR2, ODNR1, and 1163; gray filled symbols), and a site outside the bay in the central basin of Lake Erie (Bells; gray open symbols). $\mathrm{NO}_{3}^{-}$concentrations in the Sandusky River are presented as a dotted line (a, b). Note the consistent scales between years for single variables (exception: discharge) but differing scales among variables. The dotted line in (g, h) indicates a N : P ratio of 16 (note log scale on $y$ axis).

for each sampling date was estimated by multiplying Sandusky River discharge by the $\mathrm{NO}_{3}^{-}$and TKN concentrations in the Sandusky River. While point estimates of N cycling processes are not necessarily representative of the entire system, these calculations made it possible to compare the relative magnitudes of $\mathrm{N}$ sources, assimilatory uptake processes, and dissimilatory sinks in Sandusky Bay.

\subsection{Statistics}

Statistical modeling was carried out in $\mathrm{R}$ (version 3.2.4). Correlations between (1) nutrient concentrations and discharge and (2) $\mathrm{N}$ cycling rates and DIN concentrations were analyzed by linear regression. Pairwise differences between $\mathrm{NO}_{3}^{-}$and $\mathrm{NH}_{4}^{+}$uptake rates were analyzed by $t$ test. Differences in rates of denitrification, anammox, and $\mathrm{N}_{2} \mathrm{O}$ produc- tion by date were analyzed by one-way analysis of variance (ANOVA). Differences in $\mathrm{NO}_{3}^{-}$uptake, $\mathrm{NH}_{4}^{+}$uptake, and $\mathrm{N}$ fixation by date and station were analyzed by two-way interaction effects ANOVA. In all cases, date was treated as a fixed effect and temporal autocorrelation was avoided owing to the spacing of sampling dates approximately 1 month apart.

\section{Results}

Discharge from the Sandusky River was highly episodic in both years (Fig. 2k, l) and dominated by significant rain events. Owing to more frequent and intense precipitation in 2015, peak discharge was 1 order of magnitude higher than in $2016 . \mathrm{NO}_{3}^{-}$and $\mathrm{PO}_{4}^{3-}$ concentrations were positively correlated with discharge $\left(\mathrm{NO}_{3}^{-}: \mathrm{df}=135, R^{2}=0.26, p<\right.$ 

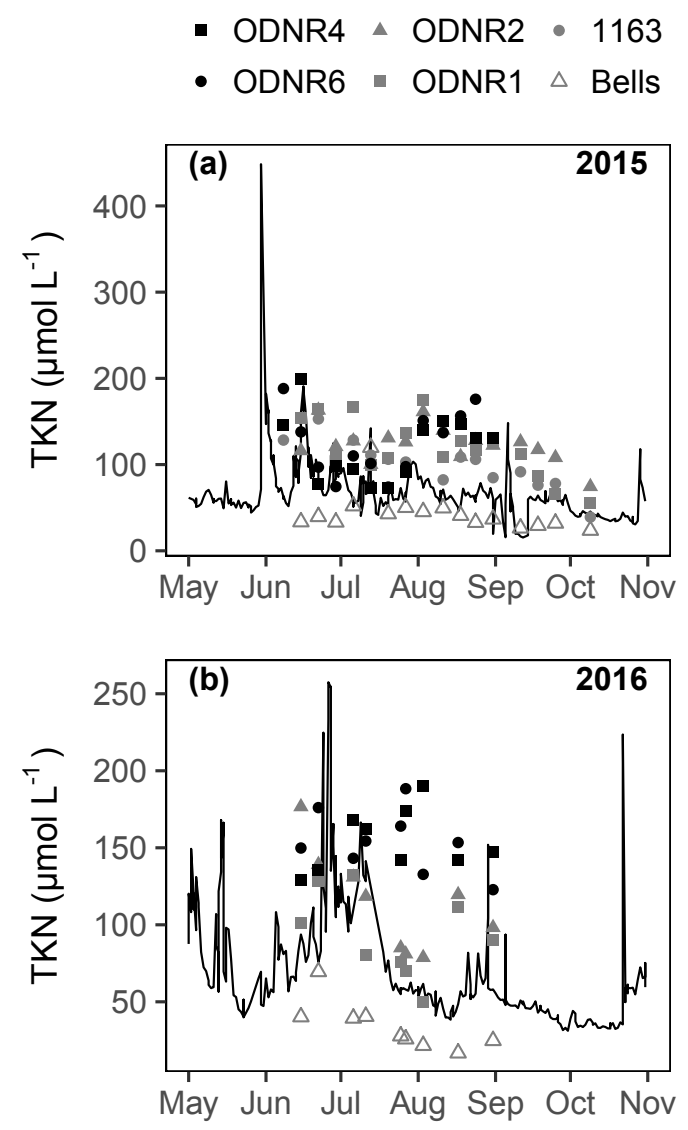

Figure 3. Total Kjeldahl nitrogen (TKN) concentrations in the Sandusky River (line) and in Sandusky Bay (symbols) in (a) 2015 and (b) 2016. Note the difference in $y$ axis scales between panels (a) and (b).

$\left.0.0001 ; \mathrm{PO}_{4}^{3-}: \mathrm{df}=135, R^{2}=0.05, p<0.01\right)$, but $\mathrm{NH}_{4}^{+}$ concentrations were not correlated with discharge $(\mathrm{df}=135$; $\left.R^{2}=0.01 ; p=0.08\right)$. The shortest hydraulic residence time in 2015 was 8 days during peak discharge, but in 2016 it was 82 days owing to lower peak discharge. In both years, as discharge decreased in the late summer and early fall, hydraulic residence time increased to several months.

$\mathrm{NO}_{3}^{-}$concentrations ranged from below detection $\left(<0.1 \mu \mathrm{mol} \mathrm{L}{ }^{-1}\right)$ to a maximum of $>650 \mu \mathrm{mol} \mathrm{L}^{-1}$ in 2015 and $65 \mu \mathrm{mol} \mathrm{L}^{-1}$ in 2016 (Fig. 2a, b). Temporal patterns in $\mathrm{NO}_{3}^{-}$concentration in the bay followed those in the Sandusky River. In both years, the greatest $\mathrm{NO}_{3}^{-}$concentrations were observed in June and July followed by a decline in August that continued through October. The magnitude of these shifts was greater for the inner bay stations (ODNR4, ODNR6) than the outer bay stations (ODNR1, ODNR2, 1163). $\mathrm{NO}_{3}^{-}$concentrations were generally higher in the Sandusky River than in Sandusky Bay (Fig. 2a, b), whereas TKN concentrations displayed an opposite trend (Fig. 3). $\mathrm{NO}_{3}^{-}$concentrations at the nearshore Lake Erie station

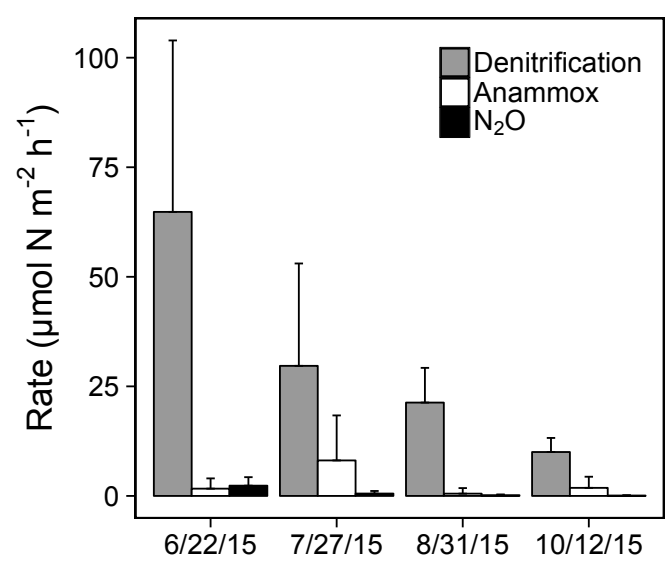

Figure 4. Denitrification, anammox, and $\mathrm{N}_{2} \mathrm{O}$ production rates at station 1163. Error bars represent $+1 \mathrm{SD}$.

(Bells) displayed similar temporal patterns to those in the bay in 2015, whereas $\mathrm{NO}_{3}^{-}$concentrations at Bells were consistently higher than those in the bay in $2016 . \mathrm{NH}_{4}^{+}$concentrations ranged from below detection $\left(<0.5 \mu \mathrm{mol} \mathrm{L}^{-1}\right)$ to $17.5 \mu \mathrm{mol} \mathrm{L}^{-1}$ across sites during the sampling period and were generally lower in 2016 than 2015 (Fig. 2c, d). The greatest $\mathrm{NH}_{4}^{+}$concentrations were observed in the inner bay, and these spikes occurred episodically throughout the sampling season. $\mathrm{PO}_{4}^{3-}$ concentrations ranged from below detection $\left(<0.04 \mu \mathrm{mol} \mathrm{L}^{-1}\right)$ to $4.25 \mu \mathrm{mol} \mathrm{L}^{-1}$ across sites during the sampling period, and the highest concentrations were observed in the inner bay (Fig. 2e, f). The molar ratio of DIN to dissolved inorganic $\mathrm{P}\left(\mathrm{N}: \mathrm{P} ; \mathrm{NO}_{3}^{-}+\mathrm{NH}_{4}^{+}\right.$to $\left.\mathrm{PO}_{4}^{3-}\right)$ was highly variable throughout the sampling period in 2015 and 2016, ranging from over 10000 to below Redfield stoichiometry (16:1) (Fig. 2g, h). In general, high $\mathrm{N}: \mathrm{P}$ values were observed earlier in the season, and low $\mathrm{N}: \mathrm{P}$ values were observed later in the season as $\mathrm{NO}_{3}^{-}$concentrations declined. Chl a concentrations ranged from 3.5 to nearly $150 \mu \mathrm{g} \mathrm{L}^{-1}$ across sites throughout the sampling period in 2015 and 2016 (Fig. 2i, j). Maximum chl $a$ concentrations in both years occurred in late August to early September, approximately 1 month after the peak in $\mathrm{NO}_{3}^{-}$and $\mathrm{PO}_{4}^{3-}$ concentrations.

Sediment N removal processes were active across the sampling period at station 1163 in 2015 (Fig. 4). Denitrification rates ranged from 10.02 to $64.81 \mu \mathrm{mol} \mathrm{N} \mathrm{m}{ }^{-2} \mathrm{~h}^{-1}$ over all sampled dates, decreasing over time coincident with declines in water column $\mathrm{NO}_{3}^{-}$(ANOVA; $F_{3,24}=6.53 ; p<0.01$ ). Anammox activity was detected on all sampling dates but not in all replicate sediment cores. Anammox rates ranged from 0.52 to $8.10 \mu \mathrm{mol} \mathrm{N} \mathrm{m}^{-2} \mathrm{~h}^{-1}$ across sampled dates, displaying no clear temporal trend (ANOVA; $F_{3,24}=2.60 ; p=$ $0.08)$. The majority of measured anammox rates were less than $7 \mu \mathrm{mol} \mathrm{N} \mathrm{m}{ }^{-2} \mathrm{~h}^{-1}$, with the exception of two cores on 27 July that displayed elevated anammox rates of 15.15 and 

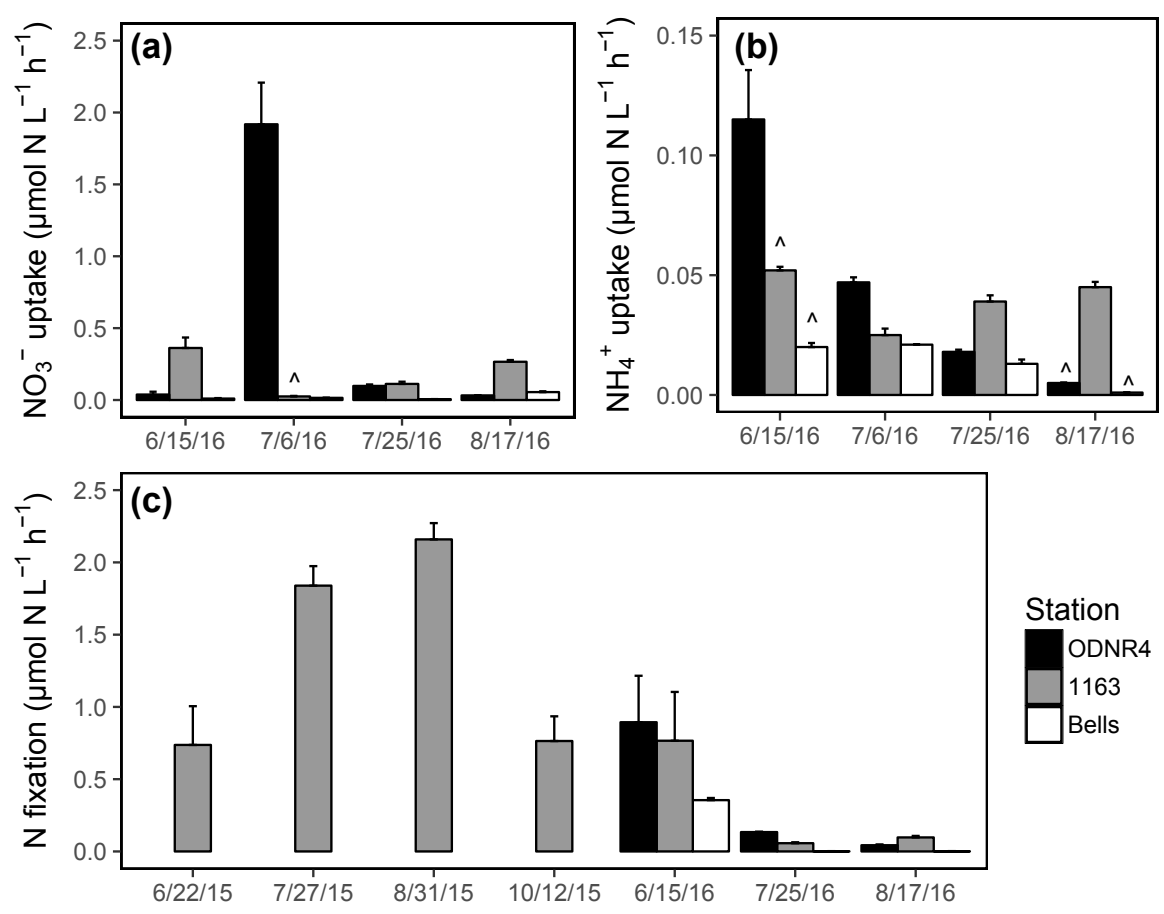

Figure 5. (a) $\mathrm{NO}_{3}^{-}$uptake rates, (b) $\mathrm{NH}_{4}^{+}$uptake rates, and (c) $\mathrm{N}$ fixation rates in Sandusky Bay. Rates were measured at stations ODNR4 (black), 1163 (gray), and Bells (white). Note the differing $y$ axis scales among panels. Error bars represent +1 SD. Carat symbols (`) indicate incubations in which the ${ }^{15} \mathrm{~N}$ addition exceeded $10 \%$ of the ambient $\mathrm{NO}_{3}^{-}$or $\mathrm{NH}_{4}^{+}$concentration, owing to unexpectedly low ambient concentrations.

$30.75 \mu \mathrm{mol} \mathrm{N} \mathrm{m}{ }^{-2} \mathrm{~h}^{-1} . \mathrm{N}_{2} \mathrm{O}$ production rates at station 1163 ranged from 0.09 to $2.34 \mu \mathrm{mol} \mathrm{N} \mathrm{m}{ }^{-2} \mathrm{~h}^{-1}$ across sampled dates, decreasing over time coincident with declines in water column $\mathrm{NO}_{3}^{-}$(ANOVA; $F_{3,24}=6.85 ; p<0.01$ ). Denitrification, anammox, and $\mathrm{N}_{2} \mathrm{O}$ production made up an average of 84,14 , and $2 \%$ of sediment $\mathrm{N}$ removal, respectively.

$\mathrm{NO}_{3}^{-}$and $\mathrm{NH}_{4}^{+}$uptake was active in the inner bay, outer bay, and nearshore Lake Erie throughout the sampling period in 2016. $\mathrm{NO}_{3}^{-}$uptake rates ranged from 0.01 to $1.92 \mu \mathrm{mol} \mathrm{N} \mathrm{L}^{-1} \mathrm{~h}^{-1}$ (Fig. 5a), and $\mathrm{NH}_{4}^{+}$uptake rates ranged from 0.001 to $0.11 \mu \mathrm{molNL} \mathrm{N}^{-1} \mathrm{~h}^{-1}$ (Fig. 5b). There was a significant interaction between the effects of date and location on $\mathrm{NO}_{3}^{-}$uptake (ANOVA; $F_{6,24}=133.14 ; p<0.0001$ ) and $\mathrm{NH}_{4}^{+}$uptake (ANOVA; $F_{6,24}=19.43 ; p<0.0001$ ). Overall, $\mathrm{NO}_{3}^{-}$and $\mathrm{NH}_{4}^{+}$uptake rates were higher within the bay than at the nearshore Lake Erie station. Rates of $\mathrm{NO}_{3}^{-}$ uptake were significantly higher than rates of $\mathrm{NH}_{4}^{+}$uptake ( $t$ test; $\mathrm{df}=35 ; T=2.41 ; p=0.02$ ). As a result of ambient concentrations being lower than anticipated, there were several instances when the ${ }^{15} \mathrm{~N}$-labeled fraction of $\mathrm{NO}_{3}^{-}$or $\mathrm{NH}_{4}^{+}$ exceeded $10 \%$ (marked with ${ }^{\wedge}$ in Fig. 5a, b). However, the elevation of substrate concentration was not associated with unusually high uptake rates in comparison with other dates at the same site, and these observations were retained in the dataset.
Water column $\mathrm{N}$ fixation was active throughout the sampling period in 2015 and 2016, with rates ranging from 0.06 to $2.16 \mu \mathrm{mol} \mathrm{N} \mathrm{L}^{-1} \mathrm{~h}^{-1}$ (Fig. $5 \mathrm{c}$ ). $\mathrm{N}$ fixation rates varied significantly by date (ANOVA; $F_{7,25}=156.33 ; p<0.0001$ ), and rates across dates fell into significant groupings (marked with letters in Fig. 5c). The highest observed rates of $\mathrm{N}$ fixation occurred in late July and late August of 2015. The lowest observed rates of $\mathrm{N}$ fixation occurred in late July and late August of 2016. Areal rates of $\mathrm{N}$ fixation ranged from 309.5 to $906.9 \mu \mathrm{mol} \mathrm{N} \mathrm{m}{ }^{-2} \mathrm{~h}^{-1}$ in 2015 and 0.2 to $187.8 \mu \mathrm{mol} \mathrm{N} \mathrm{m}^{-2} \mathrm{~h}^{-1}$ in 2016.

Metagenomic analysis revealed that Planktothrix spp. dominated the cyanobacterial community (22-99\% of iTag reads) on all but one sampled date at station 1163 . Diazotrophs (Aphanizomenon sp. and Dolichospermum spp.) were present on all sampled dates and made up a minor assemblage of the cyanobacterial community $(1-33 \%$ of iTag reads; Fig. 6).

DIN concentration was positively correlated with daily volumetric rates of denitrification, $\mathrm{N}_{2} \mathrm{O}$ production, and $\mathrm{NO}_{3}^{-}$uptake, explaining 64,60 , and $75 \%$ of variance in mean rates, respectively (Fig. 7). Anammox rates were not correlated with DIN concentration due to the high variance observed among dates and replicate sediment cores (Fig. 7b). DIN concentration explained only $12 \%$ of variance in mean $\mathrm{NH}_{4}^{+}$uptake rates, although $\mathrm{NH}_{4}^{+}$concentration alone ex- 


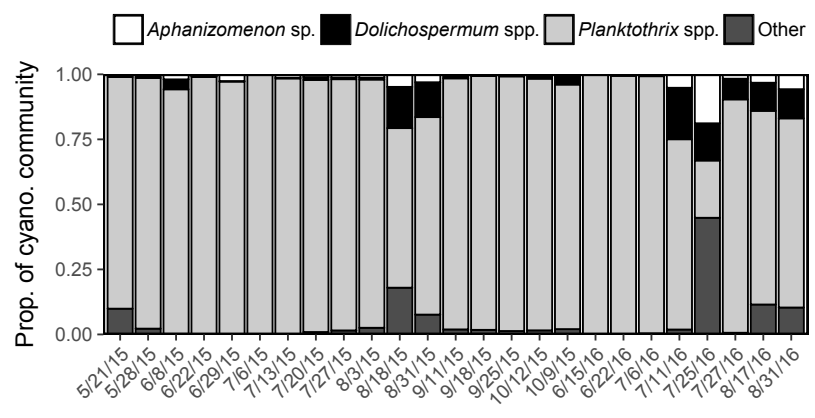

Figure 6. Proportion of cyanobacterial community derived from iTag reads in 2015 and 2016. A single operational taxonomic unit was detected for Aphanizomenon, and multiple operational taxonomic units were detected for Dolichospermum and Planktothrix.

plained $86 \%$ of variance and was positively correlated with $\mathrm{NH}_{4}^{+}$uptake. $\mathrm{N}$ fixation was not significantly correlated with DIN concentration (Fig. 7a). Ranges in daily volumetric rates of assimilatory processes $\left(\mathrm{NO}_{3}^{-}\right.$uptake, $\mathrm{NH}_{4}^{+}$uptake, $\mathrm{N}$ fixation) were several orders of magnitude higher than dissimilatory processes (denitrification, anammox, $\mathrm{N}_{2} \mathrm{O}$ production), with the exception of $\mathrm{NH}_{4}^{+}$uptake and denitrification, which were within the same magnitude (Fig. 7).

Daily rates of $\mathrm{NO}_{3}^{-}$and TKN loading from the Sandusky River varied by 5 and 2 orders of magnitude, respectively, and high loading rates were associated with high discharge (Fig. 8). $\mathrm{N}$ fixation often exceeded riverine $\mathrm{N}$ loading as a source of $\mathrm{N}$ to Sandusky Bay, particularly during periods of low discharge. $\mathrm{NO}_{3}^{-}$uptake was the dominant $\mathrm{N}$ uptake process in Sandusky Bay, outpacing $\mathrm{NH}_{4}^{+}$uptake and dissimilatory $\mathrm{N}$ removal processes (Fig. 8). On the basis of the total magnitude of ranges, the sources and demands of $\mathrm{N}$ in this system are tipped in favor of a net source to Lake Erie, ranging from a strong source during periods of high discharge to a weak source during periods of low discharge.

\section{Discussion}

\subsection{Nutrient stoichiometry}

Sandusky Bay displays considerable seasonal variation in nutrient concentrations, molar dissolved $\mathrm{N}: \mathrm{P}$ ratios, and chl $a$ concentrations, indicative of a system with dynamic changes in hydrology and biogeochemical activity. Maximum chl $a$ concentrations in both years $\left(>100 \mu \mathrm{gL}^{-1}\right)$ were similar to other hypereutrophic systems (Zhang et al., 2011; Wheeler et al., 2012; Steffen et al., 2014b), as were large swings in $\mathrm{NO}_{3}^{-}$concentrations in 2015 (Xu et al., 2010; Steffen et al., 2014b; McCarthy et al., 2016). Elevated nutrient concentrations were associated with high discharge events from the Sandusky River, demonstrating a strong watershed influence on Sandusky Bay. Indeed, the Sandusky River watershed
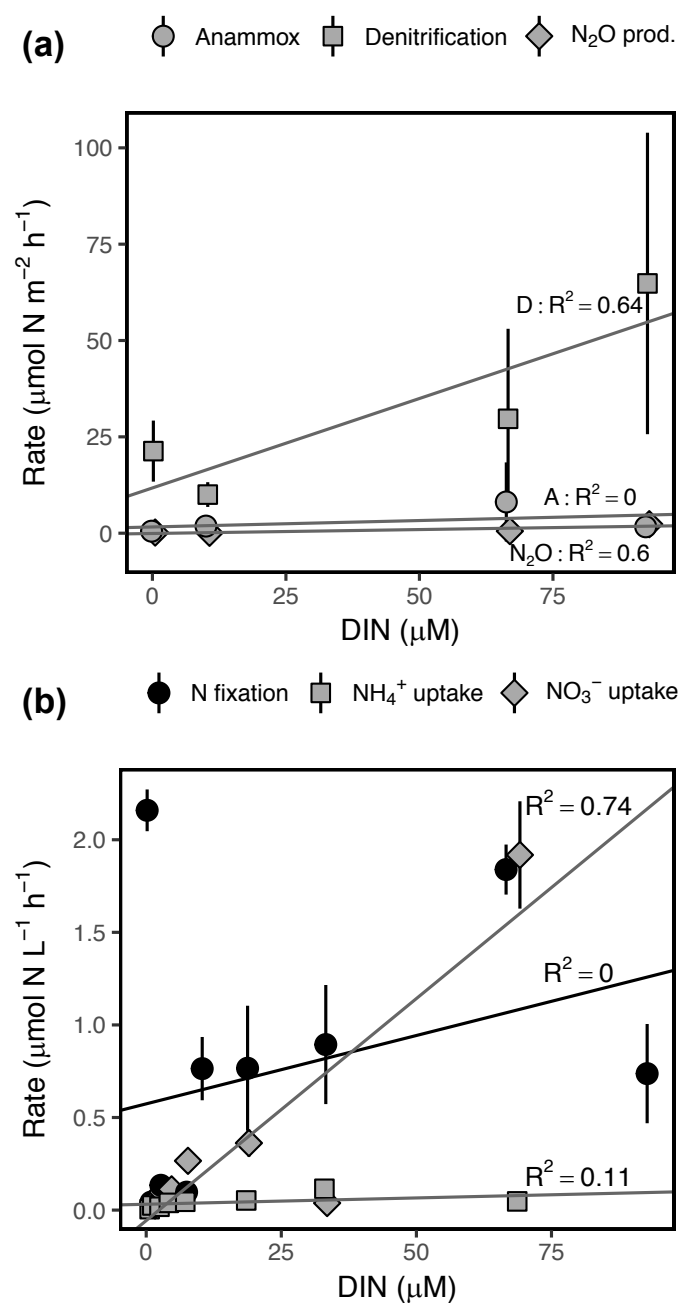

Figure 7. Rates of (a) dissimilatory and (b) assimilatory $\mathrm{N}$ cycling processes as a function of DIN concentration $\left(\mathrm{NH}_{4}^{+}+\mathrm{NO}_{3}^{-}+\mathrm{NO}_{2}^{-}\right)$. Note the differing $y$ axis scales among panels. Error bars represent \pm 1 SD. $R^{2}$ represents the adjusted $R^{2}$ for each linear regression.

comprises an area 30 times larger than the bay and delivers large nonpoint loads of $\mathrm{N}$ and $\mathrm{P}$ to its receiving waters (Robertson and Saad, 2011). Between the two study years, discharge from the Sandusky River varied substantially (tenfold higher in 2015), exhibiting large interannual variability in hydraulic residence time and nutrient concentrations.

As discharge from the Sandusky River decreased throughout the summer in both years, dissolved $\mathrm{N}$ : P ratios fell from a maximum of over 10000 to below the threshold for $\mathrm{N}$ limitation. The decline in $\mathrm{N}: \mathrm{P}$ ratios is largely driven by decreases in $\mathrm{NO}_{3}^{-}$concentration, particularly in 2015, as the range in $\mathrm{PO}_{4}^{3-}$ and $\mathrm{NH}_{4}^{+}$concentration was comparatively narrow. Consumption of $\mathrm{NO}_{3}^{-}$could be attributed to both assimilatory and dissimilatory $\mathrm{NO}_{3}^{-}$reduction. If phytoplank- 


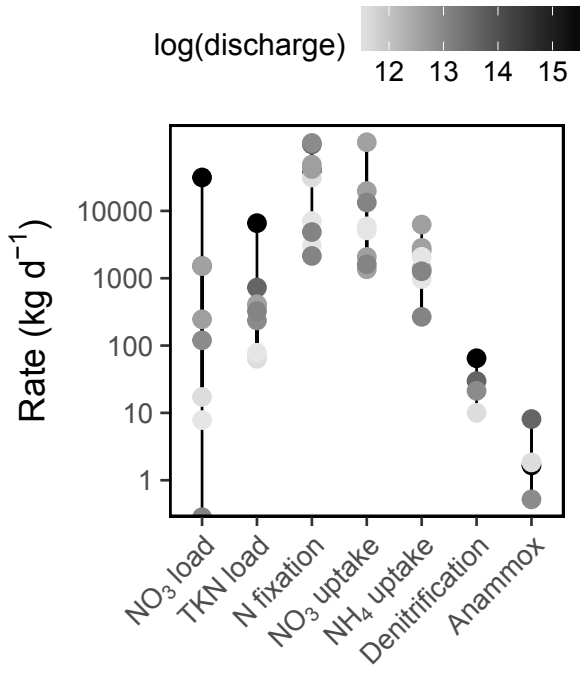

Figure 8. Rates of Sandusky River N loading and Sandusky Bay N cycling. Note the $\log$ scale on the $y$ axis. The color of each point corresponds to the log-transformed Sandusky River discharge on each date $\left(\mathrm{m}^{3} \mathrm{~d}^{-1}\right)$. Sandusky River $\mathrm{N}$ loads are presented only for the dates on which Sandusky Bay was sampled, but this is representative of the range and distribution of loads throughout the summer.

ton were solely responsible for the decline in $\mathrm{NO}_{3}^{-}$, nutrients would be expected to be drawn down in molar proportions of approximately $16 \mathrm{~N}: 1 \mathrm{P}$ (Sterner and Elser, 2002). However, N:P ratios in Sandusky Bay fall sharply throughout the summer, while $\mathrm{PO}_{4}^{3-}$ concentrations are relatively constant by comparison. Although this trend could be influenced by luxury uptake of $\mathrm{N}$ by phytoplankton and internal $\mathrm{P}$ loading from sediments (Filbrun et al., 2013; McCarthy et al., 2016), the dramatic depletion in DIN compels us to consider microbial $\mathrm{N}$ removal processes as a major mechanism for $\mathrm{N}$ drawdown in Sandusky Bay.

\subsection{N removal processes}

Marked declines in N:P with time and the occurrence of $\mathrm{N}: \mathrm{P}$ ratios $<16$ provide compelling evidence that microbial $\mathrm{N}$ removal processes (i.e., denitrification and/or anammox) consume appreciable quantities of $\mathrm{NO}_{3}^{-}$in Sandusky Bay. Sediment ${ }^{15} \mathrm{~N}$ tracer incubations indicate that the primary $\mathrm{N}$ removal mechanism in Sandusky Bay is denitrification, which comprised an average of $84 \%$ of sediment $\mathrm{N}$ removal across sampling dates. Denitrification rates were positively correlated with DIN concentration, consistent with observations that $\mathrm{N}$ supply controls sediment denitrification capacity in estuaries, lakes, and continental shelves (Seitzinger et al., 2006). Sandusky Bay exhibited efficient denitrification, with an average of only $2 \%$ of sediment $\mathrm{N}$ removal released as $\mathrm{N}_{2} \mathrm{O}$. Denitrification rates in Sandusky Bay (10.02$64.81 \mu \mathrm{mol} \mathrm{N} \mathrm{m}{ }^{-2} \mathrm{~h}^{-1}$ ) are among the highest reported for the Laurentian Great Lakes. Previous denitrification mea- surements in offshore zones of the Great Lakes vary over 4 orders of magnitude, with western and central Lake Erie exhibiting the highest rates at $51 \pm 41 \mu \mathrm{mol} \mathrm{N} \mathrm{m}{ }^{-2} \mathrm{~h}^{-1}$ (Small et al., 2014, 2016). Nearshore zones, bays, and river mouths have been observed as areas of enhanced denitrification and $\mathrm{N}_{2} \mathrm{O}$ production compared to offshore zones (McCarthy et al., 2007; Small et al., 2014, 2016; Salk et al., 2016), reinforcing that Sandusky Bay and other shallow coastal areas have the potential to act as hotspots of $\mathrm{N}$ removal in the Great Lakes system.

Anammox activity in Sandusky Bay was highly variable, even among replicate sediment cores from the same site and date. High variability was also observed in a study of potential anammox rates in the water column of Sandusky Bay and Lake Erie (Lu et al., 2018). Marked variability may be characteristic of anammox activity in freshwater environments, even across small spatial and temporal scales (Yoshinaga et al., 2011; Zhu et al., 2013, 2015). Anammox made up an average of $14 \%$ of sediment $\mathrm{N}$ removal across the sampling period, indicating that anammox activity in Sandusky Bay may be typical of shallow estuarine and freshwater systems (Thamdrup and Dalsgaard, 2002; Dalsgaard et al., 2005; Schubert et al., 2006; Dong et al., 2009; 2011; Hsu and Kao, 2013; McCarthy et al., 2016). Measurements of active anammox via isotope tracers are consistent with detection of 16S RNA associated with anammox taxa in the sediment of Lake Erie (Small et al., 2016), demonstrating that anammox has the potential to be an appreciable $\mathrm{N}$ removal pathway in this and other nearshore regions within the Great Lakes.

Whereas denitrification and anammox were the primary drivers of dissimilatory N uptake in Sandusky Bay, hydraulic residence time had a marked effect on $\mathrm{N}$ removal. In 2015, estimates of water residence time when discharge peaked in June and early July was as low as 8 days. By late July, however, hydraulic residence time increased to several months and continued to increase as discharge remained low for the remainder of the summer and early fall. Although $\mathrm{N}$ removal rates were greatest when $\mathrm{NO}_{3}^{-}$concentrations were highest, the capacity for $\mathrm{N}$ removal to substantially deplete $\mathrm{NO}_{3}^{-}$was hindered by the short hydraulic residence time within the Bay. For instance, high N removal rates in late June 2015 coincided with high $\mathrm{NO}_{3}^{-}$concentrations, but hydraulic residence times of $1-2$ weeks would enable only $\sim 1 / 4$ of $\mathrm{NO}_{3}^{-}$ to be permanently removed from the system prior to release into Lake Erie. The depletion of $\mathrm{N}$ in Sandusky Bay occurred when water residence time lengthened to several months, which provided the opportunity for assimilatory and dissimilatory processes to extensively consume $\mathrm{NO}_{3}^{-}$. Although phytoplankton uptake represents another significant $\mathrm{N}$ consumption process, the sharp decline in dissolved $\mathrm{N}: \mathrm{P}$ ratios during this period (Fig. $2 \mathrm{~g}, \mathrm{~h}$ ) indicates that dissimilatory processes (i.e., denitrification, anammox, $\mathrm{N}_{2} \mathrm{O}$ production) were important drivers of $\mathrm{NO}_{3}^{-}$concentration decline. Thus, Sandusky Bay acts as a conduit for $\mathrm{N}$ delivery from 
the Sandusky River to Lake Erie when hydraulic residence time is short but acts as a filter for $\mathrm{NO}_{3}^{-}$during periods of long hydraulic residence time. The export of nutrients from Sandusky Bay to Lake Erie during periods of high discharge is illustrated by concomitant $\mathrm{NO}_{3}^{-}$concentration spikes in Sandusky Bay and at the Lake Erie Bells station in July 2015 (Fig. 2a). Conversely, a signal of $\mathrm{NO}_{3}^{-}$export from Sandusky Bay into Lake Erie is lost during periods of low discharge, with the Bells station displaying higher $\mathrm{NO}_{3}^{-}$concentrations than bay stations in 2016 (Fig. 2b). The capacity for Sandusky Bay to act as an alternating conduit and filter for nutrients is consistent with observations in other river mouths and coastal wetlands in the Great Lakes (McCarthy et al., 2007; Larson et al., 2013; Conroy et al., 2017).

\subsection{Phytoplankton $\mathrm{N}$ acquisition}

Planktothrix-dominated phytoplankton blooms were evident in Sandusky Bay in both 2015 and 2016 (Fig. 6). Chl $a$, a proxy for total phytoplankton biomass (Becker et al., 2009; Millie et al., 2009; Davis et al., 2012), reached maximum levels approximately 1 month after maximum $\mathrm{NO}_{3}^{-}$and $\mathrm{PO}_{4}^{3-}$ concentrations were observed (Fig. 2). This offset in peak nutrient availability and peak phytoplankton biomass has been observed in other years as well (Conroy et al., 2017). The coincidence of peaks in chl $a$ with low river discharge is consistent with the idea that long hydraulic residence times create a stable physical environment in which primary producers can flourish (Michalak et al., 2013). Dissolved N : P ratios during the period of highest phytoplankton abundance approached or exceeded the threshold for $\mathrm{N}$ limitation, suggesting that Planktothrix is successful in acquiring $\mathrm{N}$ during periods of scarcity.

Given that Planktothrix is an effective competitor for DIN (Conroy et al., 2007), $\mathrm{NO}_{3}^{-}$and $\mathrm{NH}_{4}^{+}$were investigated as sources of $\mathrm{N}$ for HABs in Sandusky Bay. Indeed, $\mathrm{NO}_{3}^{-}$and $\mathrm{NH}_{4}^{+}$uptake were active throughout the summer, demonstrating that low concentrations do not equate to the absence of an actively cycling DIN pool. Transient pools of $\mathrm{NH}_{4}^{+}$generated via water column recycling (Chaffin and Bridgeman, 2014; Donald et al., 2011, 2013; Davis et al., 2015) or sediment regeneration (Paerl et al., 2011; McCarthy et al., 2016) could help to support the persistence of Planktothrix blooms in the late summer. Uptake rates were proportional to the respective concentrations of substrates, suggesting that although $\mathrm{NH}_{4}^{+}$ is a less energetically costly source of $\mathrm{N}, \mathrm{NO}_{3}^{-}$is utilized by phytoplankton to a greater extent in this system owing to a greater relative abundance.

Remineralization was not specifically measured in $\mathrm{NH}_{4}^{+}$ uptake assays, but it is likely that $\mathrm{NH}_{4}^{+}$is rapidly recycled in this system. In comparable systems, remineralization rates are on the same order as uptake rates, and this recycling represents a crucial $\mathrm{N}$ supply for cHABs (Hampel et al., 2018). The observation of higher TKN concentrations in Sandusky Bay than in the Sandusky River (Fig. 3) suggests that fixed N and assimilated $\mathrm{NO}_{3}^{-}$are recycled into TKN, which is comprised of both organic $\mathrm{N}$ forms and $\mathrm{NH}_{4}^{+}$. Given the potential for $\mathrm{NH}_{4}^{+}$remineralization to cause dilution of the ${ }^{15} \mathrm{~N}$ enriched $\mathrm{NH}_{4}^{+}$pool in $\mathrm{NH}_{4}^{+}$uptake assays, a hypothetical dilution due to remineralization was calculated by assuming a remineralization rate equivalent to the $\mathrm{NH}_{4}^{+}$uptake rate. Supposing an immediate dilution rather than a progressive dilution throughout the incubation and an isotopic composition of remineralized $\mathrm{NH}_{4}^{+}$equal to that of particulate $\mathrm{N}$, the calculation represents the maximum possible dilution that could take place during $\mathrm{NH}_{4}^{+}$uptake incubations. The resulting isotope dilution would result in an underestimation of $\mathrm{NH}_{4}^{+}$uptake by $41 \pm 11 \%$ (mean $\left.\pm \mathrm{SD}\right)$. Thus, a rapidly recycling pool of $\mathrm{NH}_{4}^{+}$could represent a significant source of $\mathrm{N}$ to Planktothrix in this system despite the difficulty in quantifying transient availability and uptake.

$\mathrm{N}$ fixation was a major $\mathrm{N}$ uptake process in Sandusky Bay, often exceeding rates of $\mathrm{NO}_{3}^{-}$and $\mathrm{NH}_{4}^{+}$uptake (Fig. 5). The phytoplankton community responsible for water column $\mathrm{N}$ fixation in Sandusky Bay is comprised largely of Aphanizomenon and Dolichospermum (Fig. 6). Areal N fixation rates $\left(309.5-906.9 \mu \mathrm{mol} \mathrm{N} \mathrm{m} \mathrm{N}^{-2} \mathrm{~h}^{-1}\right.$ in 2015 and 0.2 $187.8 \mu \mathrm{mol} \mathrm{N} \mathrm{m}{ }^{-2} \mathrm{~h}^{-1}$ in 2016) are within the range of those observed in eutrophic lakes $\left(9.2-421.2 \mu \mathrm{mol} \mathrm{N} \mathrm{m}^{-2} \mathrm{~h}^{-1}\right.$; Howarth et al., 1988, and references therein), with the exception of extremely high $\mathrm{N}$ fixation rates measured in May, July, and August 2015. The occurrence of high N fixation rates under $\mathrm{N}$ limitation in eutrophic Sandusky Bay is not surprising, but the observation of $\mathrm{N}$ fixation rates exceeding $\mathrm{NO}_{3}^{-}$and $\mathrm{NH}_{4}^{+}$uptake rates on occasions when both substrates were readily available is unanticipated.

On several occasions during periods of low discharge, riverine DIN loading alone could not meet phytoplankton uptake demands (Fig. 8). Consequently, the fixation and subsequent recycling of $\mathrm{N}$ represent an additional potential source of bioavailable $\mathrm{N}$ for cHABs in Sandusky Bay. For dates when comparisons are available, $\mathrm{N}$ fixation comprised 23.7$85.4 \%$ of total phytoplankton $\mathrm{N}$ uptake $\left(\mathrm{NO}_{3}^{-}\right.$uptake $+\mathrm{NH}_{4}^{+}$ uptake $+\mathrm{N}$ fixation) in the inner and outer bay. This range is typical of eutrophic lakes, in which $\mathrm{N}$ fixation has been observed to comprise 5.5-82.0\% of $\mathrm{N}$ inputs (Howarth et al., 1988 , and references therein). Given that a high proportion of $\mathrm{N}$ in the system is supplied via $\mathrm{N}$ fixation, even small transfers of $\mathrm{N}$ from diazotrophs could represent an important $\mathrm{N}$ source for Planktothrix. Specifically, N leaking out of actively $\mathrm{N}$-fixing cells or from decomposing cells has the potential to supplement the $\mathrm{N}$ supply for non-diazotrophs (Ohlendieck et al., 2000; Beversdorf et al., 2013). Indeed, TKN concentrations were higher in Sandusky Bay than in the Sandusky River during times when $\mathrm{NO}_{3}^{-}$concentrations in the bay were very low (Figs. 2, 3), suggesting that fixed $\mathrm{N}$ is recycled into the dissolved $\mathrm{N}$ pool that can be taken up by non-diazotrophs such as Planktothrix. Thus, both riverine $\mathrm{N}$ loading and $\mathrm{N}$ fixation represent sources of bioavailable $\mathrm{N}$ 
that Planktothrix may scavenge during periods of $\mathrm{N}$ limitation in Sandusky Bay.

Rates of $\mathrm{N}$ fixation were not correlated with DIN concentrations, a surprising outcome considering that DIN uptake is a less energetically costly process and is predicted to outcompete $\mathrm{N}$ fixation when DIN is available (Holl and Montoya, 2005). While this result is unexpected, previous work has shown that the presence of DIN suppresses the synthesis of the nitrogenase complex but not the activity of the existing enzyme (Fogg, 1971; Wolk, 1973; Chang et al., 1980), and high concentrations of $\mathrm{NO}_{3}^{-}$only partially suppress heterocyst formation (Ogawa and Carr, 1969; Ohmori and Hattori, 1972). Indeed, $\mathrm{N}$ fixation in the presence of DIN and at dissolved $\mathrm{N}: \mathrm{P}$ ratios greater than 16 have been observed elsewhere (Chen et al., 1996; Spröber et al., 2003; Voss et al., 2004; Moisander et al., 2008; Gao et al., 2014). Given the dynamic nature of hydrology and riverine DIN loading in river-lake mixing zones and estuarine systems, there may be energetic gains from maintaining $\mathrm{N}$ fixation machinery that can be utilized quickly following sudden swings in $\mathrm{N}$ availability (Moisander et al., 2012). While the precise causes of high rates of $\mathrm{N}$ fixation in this hypereutrophic system are not readily apparent, the occurrence of this process indicates that Sandusky Bay not only acts as a conduit for riverine DIN loading to Lake Erie but also a source. Therefore, watershed $\mathrm{N}$ management aimed at minimizing $\mathrm{N}$ export to Lake Erie may be offset in part by the introduction of $\mathrm{N}$ via $\mathrm{N}$ fixation in Sandusky Bay.

\section{$4.4 \mathrm{~N}$ budget}

Sandusky Bay displays dynamic swings in hydraulic and nutrient regimes yet consistently develops seasonal $\mathrm{N}$ limitation and blooms of Planktothrix in the late summer. An examination of the $\mathrm{N}$ budget in this system will help to characterize the role of this Great Lakes drowned river mouth in mediating $\mathrm{N}$ delivery to Lake Erie (Conroy et al., 2017). On the whole, Sandusky Bay is a source of N to Lake Erie, both as a conduit of watershed $\mathrm{N}$ loading and through introductions of fixed $\mathrm{N}$. The magnitude of $\mathrm{N}$ delivered downstream is highly dependent on Sandusky River discharge (Figs. 2, 8). During portions of the year when riverine DIN loading is low, $\mathrm{N}$ fixation supplements DIN loading to meet assimilatory and dissimilatory $\mathrm{N}$ demands, representing a large and crucial balance for the $\mathrm{N}$ budget in Sandusky Bay. N fixation has been suggested as a mechanism for balancing the $\mathrm{N}$ budget in favor of a net source in other eutrophic lakes (Cook et al., 2010). N fixation and phytoplankton DIN uptake transfer $\mathrm{N}$ into organic forms that can be recycled within the system or delivered downstream. The dominance of assimilatory processes suggests that although DIN concentrations are often low in Sandusky Bay, there is an actively cycling $\mathrm{N}$ stock within the phytoplankton community that may be utilized by Planktothrix. Dissimilatory sinks, although on a smaller magnitude, represent a permanent $\mathrm{N}$ sink that may have a greater influence on the development of $\mathrm{N}$ limitation than assimilatory processes.

The mass balance of $\mathrm{N}$ in Sandusky Bay undergoes rapid and dramatic seasonal transitions, shifting the role of the bay from a strong to a weak source of $\mathrm{N}$ to Lake Erie. Previous work suggests oscillations between excess $\mathrm{N}$ abundance and $\mathrm{N}$ limitation that are consistent from year to year (Conroy et al., 2007, 2017; Davis et al., 2015). During periods of high discharge and $\mathrm{N}$ loading, short hydraulic residence times prevent substantial processing of $\mathrm{N}$ and DIN is flushed into Lake Erie. When Sandusky River discharge and N loading are low, sediment $\mathrm{N}$ removal and $\mathrm{N}$ recycling by phytoplankton result in a smaller pulse of $\mathrm{N}$ delivery to Lake Erie that has been extensively processed into organic forms. Sandusky Bay thus oscillates between acting as a conduit and a filter of $\mathrm{N}$. Discharge-driven oscillations in $\mathrm{N}$ cycling and downstream delivery may be a common feature in river-lake mixing zones and estuaries, most notably Narragansett Bay (Fulweiler et al., 2007; Fulweiler and Heiss, 2014).

Future projections suggest that climate change will create conditions that are likely to intensify the role of Sandusky Bay and comparable systems as conduits of downstream nutrient delivery. Overall precipitation in the watershed is expected to increase and become dominated by incidences of extreme precipitation (Prein et al., 2017). Moreover, increases in precipitation are predicted to be accompanied by enhanced riverine $\mathrm{N}$ loading in the near future (Sinha et al., 2017). Increases in the frequency and intensity of discharge and riverine $\mathrm{N}$ loading will likely diminish the capacity for Sandusky Bay to transform and remove N, thus favoring the downstream export of DIN. The increased export of nutrients downstream may support cHABs in the central basin of Lake Erie and exacerbate water quality issues downstream, including hypoxia in the central basin of Lake Erie and the St. Lawrence Estuary (Lehmann et al., 2009; Michalak et al., 2013). Similar climate-change-driven shifts in water quality are anticipated in other coastal systems such as the Gulf of Mexico, where enhanced riverine $\mathrm{N}$ delivery and predicted increases in magnitude and timing of precipitation will make hypoxia mitigation efforts even more difficult (Turner et al., 2008, 2012). Sandusky Bay may thus serve as a harbinger for what can be expected in many coastal systems that are responding to climate change and increases in $\mathrm{N}$ loading.

Data availability. Data and associated content for this manuscript can be found at https://github.com/KateriSalk/SanduskyBay_ NitrogenCycle.git (Salk et al., 2018a, b).

Author contributions. This study was designed by KRS, NEO, GSB, and RMLM. Field sampling was carried out by KRS, GSB, RMLM, JDC, and associated research groups. Sample and data analysis were carried out by KRS, NEO, and JDC. KRS prepared 
the manuscript with contributions from NEO, GSB, RMLM, and JDC.

Competing interests. The authors declare that they have no conflict of interest.

Acknowledgements. We thank Taylor Tuttle, Emily Davenport, Hasand Gandhi, Kristen Slodysko, Erica Fox, Kat Rossos, Callie Nauman, and Keara Stanislawczyk for their assistance in the field and laboratory. Thank you to Silvia Newell and Mark McCarthy for assistance with MIMS analysis and Peggy Ostrom, Stephen Hamilton, and Silvia Newell for feedback on the manuscript. This research was supported by the NSF Graduate Research Fellowship (no. 497 DGE1424871), the Michigan State University (MSU) College of Natural Science Hensley Fellowship, the MSU Rose Fellowship in Water Research, the MSU WaterCube program, the Ohio Department of Higher Education's Harmful Algal Bloom Research Initiative (no. R/HAB-2-BOR), and the Ohio Sea Grant College Program (no. R/ER-114). The work conducted by the U.S. DOE Joint Genome Institute, a DOE Office of Science User Facility, was supported by the Office of Science of the U.S. DOE under contract no. DE-AC02-05CH11231.

Edited by: Gwenaël Abril

Reviewed by: two anonymous referees

\section{References}

Becker, R. H., Sultan, M. I., Boyer, G. L., Twiss, M. R., and Konopko, E.: Mapping cyanobacterial blooms in the Great Lakes using MODIS, J. Great Lakes Res., 35, 447-453, https://doi.org/10.1016/j.jglr.2009.05.007, 2009.

Beversdorf, L. J., Millter, T. R., and McMahon, K. D.: The role of nitrogen fixation in cyanobacterial bloom toxicity in a temperate, eutrophic lake, PLoS ONE, 8, e56103, https://doi.org/10.1371/journal.pone.0056103, 2013.

Bricker, S. B., Longstaff, B., Dennison, W., Jones, A., Boicourt, K., Wicks, C., and Woerner, J.: Effects of nutrient enrichment in the nation's estuaries: A decade of change, Harmful Algae, 8, 21-32, https://doi.org/10.1016/j.hal.2008.08.028, 2008.

Bullerjahn, G. S., McKay, R. M. L., Davis, T. W., Baker, D. B., Boyer, G. L., D’Anglada, L. V., Doucette, G. J., Ho, J. C., Irwin, E. G., Kling, C. L., Kudela, R. M., Kurmayer, R., Michalak, A. M., Ortiz, J. D., Otten, T. G., Paerl, H. W., Qin, B., Sohngen, B. L., Stumpf, R. P., Visser, P. M., and Wilhelm, S. W.: Global solutions to regional problems: Collecting global expertise to address the problem of harmful cyanobacterial blooms. A Lake Erie case study, Harmful Algae, 54, 223 238, https://doi.org/10.1016/j.hal.2016.01.003, 2016.

Caporaso, J. G., Kuczynski, J., Stombaugh, J., Bittinger, K., Bushman, F. D., Costello, E. K., Fierer, N., Peña, A. G., Goodrich, J. K., Gordon, J. I, Huttley, G. A., Kelley, S. T., Knights, D., Koenig, J. E., Ley, R. E., Lozupone, C. A., McDonald, D., Muegge, B. D., Pirrung, M., Reeder, J., Sevinsky, J. R., Turnbaugh, P. J., Walters, W. A., Widmann, J., Yatsunenko, T., Zaneveld, J., and Knight, R.: QIIME allows analysis of high- throughput community sequencing data, Nat. Methods, 7, 335336, 2010.

Carmichael, W. W. and Boyer, G. L.: Health impacts from cyanobacteria harmful algae blooms: Implications for the North American Great Lakes, Harmful Algae, 54, 194-212, 2016.

Chaffin, J. D. and Bridgeman, T. B.: Organic and inorganic nitrogen utilization by nitrogen-stressed cyanobacteria during bloom conditions, J. Appl. Phycol., 26, 299-309, https://doi.org/10.1007/s10811-013-0118-0, 2014.

Chaffin, J. D., Bridgeman, T. B., and Bade, D. L.: Nitrogen constrains the growth of late summer cyanobacterial blooms in Lake Erie, Adv. Microbiol., 3, 16-26, https://doi.org/10.4236/aim.2013.36A003 2013.

Chang, T. P.: Mucilage sheath as a barrier to carbon uptake in a cyanophyte, Oscillatoria rubescans, D.C. Arch. Hydrobiol, 88 , 128-133, 1980.

Chen, Y. B., Zehr, J. P., and Mellon, M.: Growth and nitrogen fixation of the diazotrophic filamentous nonheterocystous cyanobacterium Trichodesmium sp. IMS 101 in defined media: Evidence for a circadian rhythm, J. Phycol., 32, 916-923, 1996.

Conroy, J. D., Quinlan, E. L., Kane, D. D., and Culver, D. A.: Cylindrospermopsis in Lake Erie: Testing its association with other cyanobacterial genera and major limnological parameters, J. Great Lakes Res., 33, 519-535, https://doi.org/10.3394/03801330(2007)33[519:CILETI]2.0.CO;2, 2007.

Conroy, J. D., Kane, D. D., Quinlan, E. L., Edwards, W. J., and Culver, D. A.: Abiotic and biotic controls of phytoplankton biomass dynamics in a freshwater tributary, estuary, and large lake ecosystem: Sandusky Bay (Lake Erie) chemostat, Inland Waters, 7, 473-492, https://doi.org/10.1080/20442041.2017.1395142, 2017.

Cook, P. L. M., Aldridge, K. T., Lamontagne, S., and Brookes, J. D.: Retention of nitrogen, phosphorus and silicon in a large semi-arid riverine lake system, Biogeochemistry, 99, 49-63, https://doi.org/10.1007/s10533-009-9389-6, 2010.

Dabundo, R., Lehmann, M. F., Treibergs, L., Tobias, C. R., Altabet, M. A., Molsander, P. H., and Granger, J.: The contamination of commercial ${ }^{15} \mathrm{~N}_{2}$ gas stocks with ${ }^{15} \mathrm{~N}$ labeled nitrate and ammonium and consequences for nitrogen fixation measurements, PLoS ONE, 9, e110335, https://doi.org/10.1371/journal.pone.0110335, 2014.

Dalsgaard, T., Nielsen, L. P., Brotas, V., Viaroli, P., Underwood, G., Nedwell, D., Sundbäck, K., Rysgaard. S., Miles, A., Bartoli, M., Dong, L., Thornton, D. C. O., Ottosen, L. D. M., Castaldelli, G., and Risgaard-Petersen, N.: Protocol handbook for NICE- Nitrogen cycling in estuaries, National Environmental Research Institute, Silkeborg, Denmark, 2000.

Dalsgaard, T., Thamdrup, B., and Canfield, D. E.: Anaerobic ammonium oxidation (anammox) in the marine environment, Res. Microbiol., 156, 45-464, https://doi.org/10.1016/j.resmic.2005.01.011, 2005.

Davis, T. W., Koch, F., Marcoval, M. A., Wilhelm, S. W., and Gobler, C. J.: Mesozooplankton and microzooplankton grazing during cyanobacterial blooms in the western basin of Lake Erie, Harmful Algae, 15, 26-35, https://doi.org/10.1016/j.hal.2011.11.002, 2012.

Davis, T. W., Bullerjahn, G. S., Tuttle, T., McKay, R. M. L., and Watson, S. B.: Effects of increasing nitrogen and phosphorus concentrations on phytoplankton commu- 
nity growth and toxicity during Planktothrix blooms in Sandusky Bay, Lake Erie, Environ. Sci. Tech., 49, 7197-7207, https://doi.org/10.1021/acs.est.5b00799, 2015.

Donald, D. B., Bogard, M. J., Finlay, K., and Leavitt, P. R.: Comparative effects of urea, ammonium, and nitrate on phytoplankton abundance, community composition, and toxicity in hypereutrophic freshwaters, Limnol. Oceanogr., 56, 2161-2175, https://doi.org/10.4319/lo.2011.56.6.2161, 2011.

Donald, D. B., Bogard, M. J., Finlay, K., Bunting, L., and Leavitt, P. R.: Phytoplankton-specific response to enrichment of phosphorus-rich surface waters with ammonium, nitrate, and urea, PLoS ONE, 8, E53277, https://doi.org/10.1371/journal.pone.0053277, 2013.

Dong, L. F., Smith, C. J., Papaspyrou, S., Stott, A., Osborn, A. M., and Nedwell, D. B.: Changes in benthic denitrification, nitrate ammonification, and anammox process rates and nitrate reductase gene abundances along an estuarine nutrient gradient (the Colne Estuary, United Kingdom), Appl. Environ. Microbiol., 75, 3171-3179, https://doi.org/10.1128/AEM.02511-08, 2009.

Dong, L. F., Sobey, M. N., Smith, C. J., Rusmana, I., Phillips, W., Scott, A., Osborn, A. M., and Nedwell, D. B.: Dissimilatory reduction of nitrate to ammonium, not denitrification or anammox, dominates benthic nitrate reduction in tropical estuaries, Limnol. Oceanogr., 56, 279-291, https://doi.org/10.4319/lo.2011.56.1.0279, 2011.

Dugdale, R. C. and Wilkerson, F. P.: The use of ${ }^{15} \mathrm{~N}$ to measure nitrogen uptake in eutrophic oceans: Experimental considerations, Limnol. Oceanogr., 31, 673-689, 1986.

Edgar, R. C.: Search and clustering orders of magnitude faster than BLAST, Bioinformatics, 26, 2460-2461, 2010.

Filbrun, J. E., Conroy, J. D., and Culver, D. A.: Understanding seasonal phosphorus dynamics to guide effective management of shallow, hypereutrophic Grand Lake St. Marys, Ohio, Lake Reservoir Manage., 29, 165-178, 2013.

Fogg, G. E.: Nitrogen fixation in lakes, Plant Soil, 35, 393-401, 1971.

Foy, R., Gibson, C., and Smith, R.: The influence of day length, light intensity and temperature on the growth rates of planktonic blue-green algae, Brit. Phycol. J., 11, 151-163, 1976.

Fulweiler, R. W. and Heiss, E. M.: (Nearly) a decade of directly measured sediment $\mathrm{N}_{2}$ fluxes: What can Narragansett Bay tell us about the global ocean nitrogen budget?, Oceanogr., 27, 184195, https://doi.org/10.5670/oceanog.2014.22, 2014.

Fulweiler, R. W., Nixon, S. W., Buckley, B. A., and Granger, S. L.: Reversal of the net dinitrogen gas flux in coastal marine sediments, Nature, 448, 180-182, https://doi.org/10.1038/nature05963, 2007.

Gao, G., O’Neil, J. M., Stoecker, D. K., and Cornwell, J. C.: Photosynthesis and nitrogen fixation during cyanobacteria blooms in an oligohaline and tidal freshwater estuary, Aquat. Microb. Ecol., 72, 127-142, https://doi.org/10.3354/ame01692, 2014.

Gobler, C. J., Burkholder, J. M., Davis, T. W., Harke, M. J., Johengen, T., Stow, C. A., and Van de Waal, D. B.: The dual role of nitrogen supply in controlling the growth and toxicity of cyanobacterial blooms, Harmful Algae, 54, 87-97, 2016.

Großkopf, T., Mohr, W., Baustian, T., Schunck, H., Gill, D., Kuypers, M. M. M., Lavik, G., Schmitz, R. A., Wallace, D. W. R., and LaRoche, J.: Doubling of marine dinitrogen-fixation rates based on direct measurements, Nature, 488, 361-364, https://doi.org/10.1038/nature11338, 2012.

Hamilton, S. K. and Ostrom, N. E.: Measurements of the stable isotope ratio of dissolved $\mathrm{N}_{2}$ in ${ }^{15} \mathrm{~N}$ tracer experiments, Limnol. Oceanogr. Methods, 5, 233-240, 2007.

Hampel, J. J., McCarthy, M. J., Gardner, W. S., Zhang, L., Xu, H., Zhu, G., and Newell, S. E.: Nitrification and ammonium dynamics in Taihu Lake, China: seasonal competition for ammonium between nitrifiers and cyanobacteria, Biogeosciences, 15, 733748, https://doi.org/10.5194/bg-15-733-2018, 2018.

Havens, K. E., James, R. T., East, T. L., and Smith, V. H.: N : P ratios, light limitation, and cyanobacterial dominance in a subtropical lake impacted by non-point source nutrient pollution, Environ. Pollut., 122, 379-390, 2003.

Heisler, J., Glibert, P., Burkholder, J., Anderson, D., Cochlan, W., Dennison, W., Gobler, C., Dortch, Q., Gobler, C. J., Heil, C. A., Humphries, E., Lewitus, A., Magnien, R., Marshall, H. G., Sellner, K., Stockwell, D. A., Stoecker, D. K., and Suddleson, M.: Eutrophication and harmful algal blooms: A scientific consensus, Harmful Algae, 8, 3-13, https://doi.org/10.1016/j.hal.2008.08.006, 2008.

Ho, J. C. and Michalak, A. M.: Challenges in tracking harmful algal blooms: A synthesis of evidence from Lake Erie, J. Great Lakes Res., 41, 317-325, https://doi.org/10.1016/j.jglr.2015.01.001, 2015.

Holl, C. M. and Montoya, J. P.: Interactions between nitrate uptake and nitrogen fixation in continuous cultures of the marine diazotroph Trichodesmium (Cyanobacteria), J. Phycology, 41, 1178-1183, https://doi.org/10.1111/j.1529-8817.2005.00146.x, 2005.

Horst, G. P., Sarnelle, O., White, J. D., Hamilton, S. K., Kaul, R. B., and Bressie, J. D.: Nitrogen availability increases the toxin quota of a harmful cyanobacterium, Microcystis aeruginosa, Water Res., 54, 188-198, https://doi.org/10.1016/j.watres.2014.01.063, 2014.

Howard, D. L., Frea, J. I., Pfister, R. M., and Dugan, P. R.: Biological nitrogen fixation in Lake Erie, Science, 169, 61-62, 1970.

Howarth, R. W., Marino, R., Lane, J., and Cole, J. J.: Nitrogen fixation in freshwater, estuarine, and marine ecosystems. 1. Rates and importance, Limnol. Oceanogr., 33, 669-687, 1988.

Hsu, T.-C. and Kao, S.-J.: Technical Note: Simultaneous measurement of sedimentary $\mathrm{N}_{2}$ and $\mathrm{N}_{2} \mathrm{O}$ production and a modified ${ }^{15} \mathrm{~N}$ isotope pairing technique, Biogeosciences, 10, 7847-7862, https://doi.org/10.5194/bg-10-7847-2013, 2013.

Kana, T. M., Darkangelo, C., Hunt, M. D., Oldham, J. B., Bennett, G. E., and Cornwell, J. C.: Membrane inlet mass spectrometer for rapid high-precision determination of $\mathrm{N}_{2}, \mathrm{O}_{2}$, and $\mathrm{Ar}$ in environmental water samples, Anal. Chem., 66, 4166-4170, 1994.

Kane, D.D., Conroy, J. D., Richards, R. P., Baker, D. B., and Culver, D. A.: Re-eutrophication of Lake Erie: Correlations between tributary nutrient loads and phytoplankton biomass, J. Great Lakes Res., 40, 496-501, https://doi.org/10.1016/j.jglr.2014.02.004, 2014.

Kim, D.-K., Zhang, W., Watson, S., and Arhonditsis, G. B.: A commentary on the modeling of the causal links among nutrient loading, harmful algal blooms, and hypoxia patterns in Lake Erie, J. Great Lakes Res., 40, 117-129, https://doi.org/10.1016/j.jglr.2014.02.014, 2014. 
Kutovaya, O. A., McKay, R. M. L., Beall, B. F. N., Wilhelm, S. W., Kane, D. D., Chaffin, J. D., Bridgeman, T. B., and Bullerjahn, G. S.: Evidence against fluvial seeding of recurrent toxic blooms of Microcystis spp. in Lake Erie's western basin, Harmful Algae, 15, 71-77, 2012.

Larson, J. H., Trebitz, A. S., Steinman, A. D., Wiley, M. J., Maxur, M. C., Pebbles, V., Braun, H. A., and Seelbach, P. W.: Great Lakes rivermouth ecosystems: Scientific synthesis and management implications, J. Great Lakes Res., 39, 513-524, https://doi.org/10.1016/j.jglr.2013.06.002, 2013.

Lehmann, M. F., Barnett, B., Gélinas, Y., Gilbert, D., Maranger, R. J., Mucci, A., Sundby, B., and Thibodeau, B.: Aerobic respiration and hypoxia in the Lower St. Lawrence Estuary: Stable isotope ratios of dissolved oxygen constrain oxygen sink partitioning, Limnol. Oceanogr., 54, 2157-2169, 2009.

Lu, X., Bade, D. L., Leff, L. G., and Mou, X.: The relative importance of anammox and denitrification to total $\mathrm{N}_{2}$ production in Lake Erie, J. Great Lakes Res., in press, https://doi.org/10.1016/j.jglr.2018.03.008, 2018.

MacGregor, B. J., Van Mooy, B., Baker, B. J., Mellon, M., Moisander, P. H., Paerl, H. W., Zehr, J., Hollander, D., and Stahl, D. A.: Microbiological, molecular biological and stable isotopic evidence for nitrogen fixation in the open waters of Lake Michigan, Environ. Microbiol., 3, 205-219, 2001.

McCarthy, M. J., Gardner, W. S., Lavrentyev, P. J., Moats, K. M., Jochem, F. J., and Klarer, D. M.: Effects of hydrological flow regime on sediment-water interface and water column nitrogen dynamics in a Great Lakes coastal wetland (Old Woman Creek, Lake Erie), J. Great Lakes Res., 33, 219-231, 2007.

McCarthy, M. J., Gardner, W. S., Lehmann, M. F., Guindon, A., and Bird, D. F.: Benthic nitrogen regeneration, fixation, and denitrification in a temperate, eutrophic lake: Effects on the nitrogen budget and cyanobacteria blooms, Limnol. Oceanogr., 61, 14061423, https://doi.org/10.1002/lno.10306, 2016.

Michalak, A. M., Anderson, E. J., Beletsky, D., Bolans, S., Bosch, N. S., Bridgeman, T. B., Chaffin, J. D., Cho, K., Confesor, R., Daloglu, I., DePinto, J. V., Evans, M. A., Fahnenstiel, G. L., He, L., Ho, J. C., Jenkins, L., Johengen, T. H., Kuo, K. C., LaPorte, E., Liu, X., McWilliams, M. R., Moore, M. R., Posselt, D. J., Richards, R. P., Scavia, D., Steiner, A. L., Verhamme, E., Wright, D. M., and Zagorski, M. A.: Record-setting algal bloom in Lake Erie caused by agricultural and meteorological trends consistent with expected future conditions, P. Natl. Acad. Sci. USA, 110, 6448-6452, https://doi.org/10.1073/pnas.1216006110, 2013.

Millie, D. F., Fahnenstiel, G. L., Bressie, J. D., Pigg, R. J., Rediske, R. R., Klarer, D. M., Tester, P. A., and Litaker, R. W.: Late-summer phytoplankton in western Lake Erie (Laurentian Great Lakes): bloom distributions, toxicity, and environmental influences, Aquat. Ecol., 434, 915-934, https://doi.org/10.1007/s10452-009-9238-7, 2009.

Moisander, P. H., Paerl, H. W., and Zehr, J. P.: Effects of inorganic nitrogen on taxa-specific cyanobacterial growth and nifH expression in a subtropical estuary, Limnol. Oceanogr., 53, 2519-2532, 2008.

Moisander, P. H., Cheshire, L. A., Braddy, J., Calandrino, E. S., Hoffman, M., Piehler, M. F., and Paerl, H. W.: Facultative diazotrophy increases Cylindrospermopsis raciborskii competitiveness under fluctuating nitrogen availability, FEMS
Microbiol. Ecol., 79, 800-811, https://doi.org/10.1111/j.15746941.2011.01264.x, 2012.

Monchamp, M.-E., Pick, F. R., Beisner, B. E., and Maraner, R.: Nitrogen forms influence microcystin concentration and composition via changes in cyanobacterial community structure, PLoS ONE, 9, e85573, https://doi.org/10.1371/journal.pone.0085573, 2014.

Montoya, J. P., Voss, M., Kähler, P., and Capone, D. G.: A simple, high-precision, high-sensitivity tracer assay for $\mathrm{N}_{2}$ fixation, Appl. Environ. Microbiol., 62, 986-993, 1996.

Moon, J. B. and Carrick, H. J.: Seasonal variation of phytoplankton nutrient limitation in Lake Erie, Aquat. Microb. Ecol., 48, 61-71, 2007.

North, R. L., Guildford, S. J., Smith, R. E. H., Havens, S. M., and Twiss, M. R.: Evidence for phosphorus, nitrogen, and iron colimitation of phytoplankton communities in Lake Erie, Limnol. Oceanogr., 52, 315-328, https://doi.org/10.4319/lo.2007.52.1.0315, 2007.

Oberhaus, L., Briand, J. F., Leboulanger, C., Jacquet, S., and Humbert, J. F.: Comparative effects of the quality and quantity of light and temperature on the growth of Planktothrix agardhii and $P$. rubescens, J. Phycol., 43, 1191-1199, 2007.

Ogawa, R. E. and Carr, J. F.: The influence on nitrogen on heterocyst production in blue green algae, Limnol. Oceanogr., 14, 342-351, 1969.

Ohlendieck, U., Stuhrm, A., and Siegmund, H.: Nitrogen fixation by diazotrophic cyanobacteria in the Baltic Sea and transfer of the newly fixed nitrogen to picoplankton organisms, J. Mar. Syst., 25, 213-219, 2000 .

Ohmori, M. and Hattori, A.: Effect on nitrate on nitrogen-fixation by the blue green algae Anabaena cylindrica, Plant Cell Physiol., 13, 589-599, 1972.

Ostrom, N. E., Carrick, H. J., Twiss, M. R., and Piwinski, L.: Evaluation of primary production in Lake Erie by multiple proxies, Oecologia, 144, 115-124, 2005.

Paerl, H. W., Xu, H., McCarthy, M. J., Zhu, G., Qin, B., Li, Y., and Gardner, W. S.: Controlling harmful cyanobacterial blooms in a hyper-eutrophic lake (Lake Taihu, China): The need for a dual nutrient (N \& P) management strategy, Water Res., 45, 19731983, https://doi.org/10.1016/j.watres.2010.09.018, 2011.

Paerl, H. W., Scott, J. T., McCarthy, M. J., Newell, S. E., Gardner, W. S., Havens, K. E., Hoffman, D. K., Wilhelm, S. W., and Wurtsbaugh, W. A.: It takes two to tango: When and where dual nutrient $(\mathrm{N} \& \mathrm{P})$ reductions are needed to protect lakes and downstream ecosystems, Environ. Sci. Technol., 50, 10805-10813, https://doi.org/10.1021/acs.est.6b02575, 2016.

Pancrace, C., Barny, M. A., Ueoka, R., Calteau, A., Scalvenzi, T., Pédron, J., Barbe, V., Humbert, J.-F., and Gugger, M.: Insights into the Planktothrix genus: Genomic and metabolic comparison of benthic and planktic strains, Sci. Rep., 7, 41181, https://doi.org/10.1038/srep41181, 2017.

Parada, A., Needham, D. M., and Fuhrman, J. A.: Every base matters: assessing small subunit rRNA primers for marine microbiomes with mock communities, time series and global field samples, Environ. Microbiol., 18, 1403-1414, 2016.

Post, A. F., Dewit, R., and Mur, L. R.: Interactions between temperature and light-intensity on growth and photosynthesis of the cyanobacterium Oscillatoria agardhii, J. Plankton Res., 7, 487495, 1985. 
Prein, A. F., Rasmussen, R. M., Ikeda. K., Liu, C., Clark, M. P., and Holland, G. J.: The future intensification of hourly precipitation extremes, Nat. Clim. Change, 7, 48-52, https://doi.org/10.1038/nclimate3168, 2017.

Quast, C., Pruesse, E., Yilmaz, P., Gerken, J., Schweer, T., Yarza, P., Peplies, J., and Glöckner, F. O.: The SILVA ribosomal RNA gene database project: improved data processing and web based tools, Nucleic Acids Res., 41, D590-6, 2013.

Richards, R. P. and Baker, D. B.: Assimilation and flux of sediments and pollutants in the Sandusky River Estuary, Sandusky Bay, and the adjacent nearshore zone of Lake Erie, Final Report, Grant NA80RAD00038, 1985.

Richards, R. P., Baker, D. B., Crumrine, J. P., and Stearns, A. M.: Unusually large loads in 2007 from the Maumee and Sandusky Rivers, tributaries to Lake Erie, J. Soil Water Conserv., 65, 450462, 2010.

Risgaard-Petersen, N., Nielsen, L. P., Rysgaard, S., Dalsgaard, T., and Meyer, R. L.: Application of the isotope pairing technique in sediments where anammox and denitrification coexist, Limnol. Oceanogr. Methods, 1, 63-73, 2003

Robertson, D. M. and Saad, D. A.: Nutrient inputs to the Laurentian Great Lakes by source and watershed estimated using sparrow watershed models, J. Am. Water Resour. Assoc., 47, 1011-1033, https://doi.org/10.1111/j.1752-1688.2011.00574.x, 2011.

Salk, K. R., Ostrom, P. H., Biddanda, B. A., Weinke, A. D., Kendall, S. T., and Ostrom, N. E.: Ecosystem metabolism and greenhouse gas production in a mesotrophic northern temperate lake experiencing seasonal hypoxia, Biogeochemistry, 131, 303-319, https://doi.org/10.1007/s10533-016-0280-y, 2016.

Salk, K. R., Bullerjahn, G. S., McKay, R. M. L., Chaffin, J. D., and Ostrom, N. E.: SanduskyBay_NitrogenCycle, https: //github.com/KateriSalk/SanduskyBay_NitrogenCycle, last access: 9 May 2018a.

Salk, K. R., Bullerjahn, G. S., McKay, R. M. L., Chaffin, J. D., and Ostrom, N. E.: KateriSalk/SanduskyBay_NitrogenCycle: bg-2017-528, https://doi.org/10.5281/zenodo.1148802, 2018 b.

Sansone, F. J., Popp, B. N., and Rust, T. M.: Stable carbon isotopic analysis of low-level methane in water and gas, Anal. Chem., 69, 40-44, https://doi.org/10.1021/ac960241i, 1997.

Scavia, D., Allan, J. D., Arend, K. K., Bartell, S., Beletsky, D., Bosch, N. S., Brandt, S. B., Briland, R. D., Daloglu, I., DePinto, J. V., Dolan, D. M., Evans, M. A., Farmer, T. M., Goto, D., Han, H., Höök, T. O., Knight, R., Ludsin, S. A., Mason, D., Michalak, A. M., Richards, R. P., Roberts, J. J., Rucinski, D. K., Rutherford, E., Schwab, D. J., Sesterhenn, T. M., Zhang, H., and Zhou, Y.: Assessing and addressing the re-eutrophication of Lake Erie: Central basin hypoxia, J. Great Lakes Res., 40, 226-246, https://doi.org/10.1016/j.jglr.2014.02.004, 2014.

Scheffer, M., Rinaldi, S., Gragnani, A., Mur, L. R., and van Nes, E. H.: On the dominance of filamentous cyanobacteria in shallow, turbid lakes, Ecology, 78, 272-282, 1997.

Schubert, C. J., Durisch-Kaiser, E., Wehrli, B., Thamdrup, B., Lam, P., and Kuypers, M. M. M.: Anaerobic ammonium oxidation in a tropical freshwater system (Lake Tanganyika), Environ. Microbiol., 8, 1857-1863, https://doi.org/10.1111/j.14622920.2006.001074.x, 2006

Scott, J. and Grantz, E.: $\mathrm{N}_{2}$ fixation exceeds internal nitrogen loading as a phytoplankton nutrient source in perpet- ually nitrogen-limited reservoirs, Freshw. Sci., 32, 849-861, https://doi.org/10.1899/12-190.1, 2013.

Seitzinger, S., Harrison, J. A., Böhlke, J. K., Bouwman, A. F., Lowrance, R., Peterson, B., Tobias, C., and Van Drecht, G.: Denitrification across landscapes and waterscapes: A synthesis, Ecol. Appl., 16, 2064-2090, 2006.

Singer, E., Andreopoulos, B., Bowers, R. M., Lee, J., Deshpande, S., Chiniquy, J., Ciobanu, D., Klenk, H.-P., Zane, M., Daum, C., Clum, A., Cheng, J.-F., Copeland, A., and Woyke, T.: Next generation sequencing data of a defined microbial mock community, Sci. Data, 3, 160081, https://doi.org/10.1038/sdata.2016.81, 2016.

Sinha, E., Michalak, A. M., and Balaji, V.: Eutrophication will increase during the 21 st century as a result of precipitation changes, Science, 357, 405-408, https://doi.org/10.1126/science.aan2409, 2017.

Small, G. E., Cotner, J. B., Finlay, J. C., Stark, R. A., and Sterner, R. W.: Nitrogen transformations at the sediment-water interface across redox gradients in the Laurentian Great Lakes, Hydrobiologia, 731, 95-108, https://doi.org/10.1007/s10750-013-15697, 2014.

Small, G. E., Finlay, J. C., McKay, R. M. L., Rozmarynowycz, M. J., Brovold, S., Bullerjahn, G. S., Spokas, K., and Sterner, R. W.: Large differences in potential denitrification and sediment microbial communities across the Laurentian Great Lakes, Biogeochemistry, 128, 353-368, https://doi.org/10.1007/s10533016-0212-x, 2016.

Smit, J. T. and Steinman, A. D.: Wetland sediment phosphorus flux in response to proposed hydrologic reconnection and warming, Wetlands, 35, 655-665, https://doi.org/10.1007/s13157-0150655-1, 2015.

Spröber, P., Shafik, H. M., Présing, M., Kovács, A. W., and Herodek, S.: Nitrogen uptake and fixation in the cyanobacterium Cylindrospermopsis raciborskii under different nitrogen conditions., Hydrobiologia, 506-509, 169-174, 2003.

Steffen, M. M., Belisle, B. S., Watson, S. B., Boyer, G. L., and Wilhelm, S. W.: Status, causes and controls of cyanobacterial blooms in Lake Erie, J. Great Lakes Res., 40, 215-225, https://doi.org/10.1016/j.jglr.2013.12.012, 2014a.

Steffen, M. M., Zhu, Z., McKay, R. M. L., Wilhelm, S. W., and Bullerjahn, G. S.: Taxonomic assessment of a toxic cyanobacteria shift in hypereutrophic Grand Lake St. Marys (Ohio, USA), Harmful Algae, 33, 12-18, 2014b.

Sterner, R. W. and Elser, J. J.: Ecological Stoichiometry: The Biology of Elements from Molecules to the Biosphere, Princeton University Press, Princeton, New Jersey, 2002.

Sterner, R. W., Ostrom, P., Ostrom, N. E., Klump, J. V., Steinmanm A. D., Dreelin, E. A., Vander Zanden, M. J., and Fisk, A. T.: Grand challenges for research in the Laurentian Great Lakes, Limnol. Oceanogr., 62, 2510-2523, https://doi.org/10.1002/lno.10585, 2017.

Stow, C. A., Cha, Y., Johnson, L. T., Confesor, R., and Richards, R. P.: Long-term and seasonal trend decomposition of Maumee River nutrient inputs to western Lake Erie, Environ. Sci. Tech., 49, 3392-3400, https://doi.org/10.1021/es5062648, 2015.

Thamdrup, B. and Dalsgaard, T.: Production of $\mathrm{N}_{2}$ through anaerobic ammonium oxidation coupled to nitrate reduction in marine sediments, Appl. Environ. Microbiol., 68, 1312-1318, https://doi.org/10.1128/AEM.68.3.1312-1318.2002, 2002. 
Tremblay, J., Singh, K., Fern, A., Kirton, E. S., He, S., Woyke, T., Lee, J., Chen, F., Dangl, J. L., and Tringe, S. G.: Primer and platform effects on 16S rRNA tag sequencing, Front. Microbiol., 6, 771, https://doi.org/10.3389/fmicb.2015.00771, 2015.

Turner, R. E., Rabalais, N. A., and Justic, D.: Gulf of Mexico hypoxia: Alternate states and a legacy, Environ. Sci. Technol., 42, 2323-2327, https://doi.org/10.1021/es071617k, 2008.

Turner, R. E., Rabalais, N. A., and Justic, D.: Predicting summer hypoxia in the northern Gulf of Mexico: Redux, Marine Poll. Bull., 64, 319-324, https://doi.org/10.1016/j.marpolbul.2011.11.008, 2012.

Voss, M., Croot, P., Lochte, K., Mills, M., and Peeken, I.: Patterns of nitrogen fixation along $10^{\circ} \mathrm{N}$ in the tropical Atlantic, Geophys. Res. Lett., 31, L23S09, https://doi.org/10.1029/2004GL020127, 2004.

Welschmeyer, N. A.: Fluorometric analysis of chlorophyll a in the presence of chlorophyll $b$ and pheopigments, Limnol. Oceanogr., 39, 1985-1992, 1994.

Wheeler, S. M., Morrissey, L. A., Levine, S. N., Livingston, G. P., and Vincent, W. F.: Mapping cyanobacterial blooms in Lake Champlain's Missisquoi Bay using QuickBird and MERIS satellite data, J. Great Lakes Res., 38, 68-75, 2012.

Wolk, C. P.: Physiology and cytological chemistry of the blue-green algae, Bacterial Rev., 37, 32-101, 1973.
Wrage, N., Velthof, G. L., van Beusichem, M. L., and Oenema, O.: Role of nitrifier denitrification in the production of nitrous oxide, Soil Biol. Biochem., 33, 1723-1732, 2001.

Xu, H., Paerl, H. W., Qin, B., Zhu, G., and Gao, G.: Nitrogen and phosphorus inputs control phytoplankton growth in eutrophic Lake Taihu, China, Limnol. Oceanogr., 55, 420-432, 2010.

Yoshinaga, I., Amano, T., Yamagishi, T., Okada, K., Ueda, S., Sako, Y., and Suwa, Y.: Distribution and diversity of anaerobic ammonium oxidation (anammox) bacteria in the sediment of a eutrophic freshwater lake, Lake Kiraura, Japan, Microbes Environ., 26, 189-197, https://doi.org/10.1264/jsme2.ME10184, 2011.

Zhang, Y., Lin, S., Qian, X., Wang, Q., Qian, Y., Liu, J., and Ge, Y.: Temporal and spatial variability of chlorophyll $a$ concentration in Lake Taihu using MODIS time-series data, Hydrobiologia, 661, 235-250, https://doi.org/10.1007/s10750-010-0528-9, 2011.

Zhu, G., Wang, S., Wang, W., Wang, Y., Zhou, L., Jian, B., Op den Camp, H. J. M., Risgaard-Petersen, N., Schwark, L., Peng, Y., Hefting, M. M., Jetten, M. S. M., and Yin, C.: Hotspots of anaerobic ammonium oxidation at land-freshwater interfaces, Nat. Geosci., 6, 103-107, https://doi.org/10.1038/NGEO1683, 2013.

Zhu, G., Wang, S., Zhou, L., Wang, Y., Zhao, S., Xia, C., Wang, W., Zhou, R., Wang, C., Jetten, M. S. M., Hefting, M. M., Yin, C., and $\mathrm{Qu}, \mathrm{J} .:$ Ubiquitous anaerobic ammonium oxidation in inland waters of China: An overlooked nitrous oxide mitigation process, Sci. Rep., 5, 17306, https://doi.org/10.1038/srep17306, 2015. 